\title{
HOOD v. DUMOND: A STUDY OF THE SUPREME GOURT AND THE IDEOLOGY OF CAPITALISM
}

\author{
JACK MICHEL ${ }^{\dagger}$
}

This Comment explores the cultural and ideological meaning of a single Supreme Court decision, H.P. Hood $\mathcal{E}$ Sons v. DuMond. ${ }^{1}$ At issue in Hood was section 258-c of article 21 of the New York Agriculture and Markets Law, ${ }^{2}$ part of a body of law framed in response to the agricultural crisis of the Depression. Section 258-c was designed to control the size and scale of New York milk processing plants in order to prevent a few purchaser-dealers from dominating local milk markets and to halt the ongoing and accelerating migration of farmers from the land. In a five-to-four decision written by Justice Jackson, over angry dissents by Justices Black and Frankfurter, the Court in 1948 invalidated this New York law. In the process of invalidating New York's attempt to ameliorate the plight of its farmers, the Court rejected the long-standing cultural ideal of America as a collection of locally controlled rural communities and adopted instead a vision of a nationally controlled, industrial economy and society.

The New York law provided that the New York Commissioner of Agriculture could refuse to grant a license to a milk dealer to enter a market, build new facilities, or expand existing facilities if the dealer's plans would "tend to a destructive competition in a market already adequately served,"3 or would otherwise not be in the public interest. ${ }^{4} \mathrm{Al}$ though there was no showing that denying Boston milk distributor H.P. Hood \& Sons a license to build its third milk processing plant in the Albany-Troy region of New York actually affected the volume of

† A.B. 1970, Wesleyan University; M.A. 1977, Ph.D. Candidate (History of Culture), University of Chicago; J.D. 1985, University of Pennsylvania. The author wrote this Comment while a student at the University of Pennsylvania Law School.

1336 U.S. 525 (1949).

2 Act of Mar. 30, 1934, ch. 126, § 258-c, 1934 N.Y. Laws 564, 575-76 (codified as amended at N.Y. AGRIC. \& MkTs. LAw § 258-c (McKinney 1972 \& Supp. 1985)).

3 Id.

- See id. For Supreme Court interpretations of other provisions of the New York Agriculture and Markets Law, see Mayflower Farms v. Ten Eyck, 297 U.S. 266, 27172 (1936) (holding that distinguishing among milk dealers on the basis of date of entry into business was unconstitutional); Borden's Farm Prods. Co. v. Ten Eyck, 297 U.S. 251, 261-63 (1936) (upholding a distinction between dealers with "well-advertised trade names" and those without); Nebbia v. New York, 291 U.S. 502, 521 (1934) (upholding the fixing of minimum prices for retail milk sales). 
milk flowing in commerce, ${ }^{5}$ the Court ruled that the denial of the license under section 258-c impermissibly restricted interstate commerce. ${ }^{6}$ By virtue of Justice Jackson's expansive reading of the restrictions that the dormant commerce clause placed on the ability of states to pass economic and social legislation, Hood became one of the touchstone cases in the modern expansion of the federal commerce power. ${ }^{7}$

Hood was likewise important in the particular context of the social and cultural history of modern American agriculture. By precluding a state from controlling the size of agricultural processing operations, Hood provided a part of the legal basis for the steady increase in concentration in the food processing industry and the corresponding decline in farmer bargaining power that has characterized the recent agricultural history of America. ${ }^{8}$ Jackson's opinion implicitly legitimated the expansion of farm size and the consequent displacement of rural people

5 See Hood, 336 U.S. at 561 (Black, J., dissenting) ("[H]ere there is no evidence whatever to show that fair enforcement of the New York law would limit the total volume of New York milk available for shipment into other states."); see also infra text accompanying notes 96-101 \& 116-20.

- See Hood, 336 U.S. at 545.

7 Although a full history of the expansion of the federal commerce power in the mid-twentieth century is beyond the scope of this Comment, some understanding of the history of the dormant commerce clause is essential to a proper consideration of Hood. The dormant commerce clause rests on an inference: that the constitutional grant of power to Congress to regulate commerce among the states can be understood to preclude states from enacting legislation that affects interstate commerce even absent an affirmative exercise of the commerce power by Congress. As late as 1938, the Court limited this inference and upheld state legislation that affected commerce unless such legislation was empirically shown to burden or discriminate against commerce. See South Carolina Highway Dep't v. Barnwell Bros., 303 U.S. 177, 189 (1938). In 1945, however, the Court imported into the dormant commerce clause doctrine reasoning that focused on the economic effects of state regulation. See Southern Pac. Co. v. Arizona, 325 U.S. 761, 781 (1945) (using a "practical effects" test to invalidate an Arizona regulation on the length of trains); see also NLRB v. Jones \& Laughlin Steel Corp., 301 U.S. 1, 29-30 (1936) (noting under the positive commerce clause that while the concept of interstate commerce should not be expanded so far as to "obliterate the distinction between what is national and what is local" all intrastate activities with a "close and substantial relation to commerce" were capable of being regulated under the federal commerce power). As argued in this Comment, Hood went one step further by employing a "theoretical effects" test. See infra text accompanying notes 96-106.

Scholars have argued that the expansion of the commerce clause doctrine was motivated by "social" concerns, see, e.g., Stern, The Commerce Clause and the National Economy, 1933-1946, 59 HARv. L. REv. 645 (1946); however, an equally plausible argiument can be made that this expansion was precipitated by the expansion of the national economy and the need of business to regularize transactions. See infra text accompanying notes 149-68. For analyses of the forces leading to the growth of national economies, see D. Dowd, The Twisted Dream: Capitalist Development in the United States Since 1776, at 218-37, 290-309 (2d ed. 1977); R. Edwards, M. Reich \& T. Weisskopf, The Capitaisist System 481-99 (2d ed. 1978).

See infra notes $62-63$ and accompanying text. 
from the land..$^{\ominus}$ Finally, and in some ways most important, Hood was one of a line of Supreme Court decisions that transferred the control of economic and social life from the local to the national level. ${ }^{10}$

This Comment develops a model for reading court opinions and applies that model to Hood in order to promote an understanding of the economic and social functions of the law. ${ }^{11}$ As made forcefully apparent by the recent rise to prominence of normative critiques of legal rules and reasoning, the law is a social and cultural artifact. ${ }^{12}$ It is easier to assert this truism, however, than to explain its meaning. The model developed here is grounded in the assumption that what we take to be reality can be meaningfully understood only insofar as it is organized and described by language. From this point of view, court opinions, like other forms of discourse, can be understood as exercises in reality making. ${ }^{13}$ The legal rules that an opinion promulgates derive from the assumptions that the court makes about the nature, both actual and desired, of reality. Any opinion, in short; encodes an entire world view, in the service of which its rules operate. ${ }^{14}$

- See infra text accompanying notes 93-106.

10 See infra text accompanying notes 152-68.

11 The view taken throughout this Comment is heavily influenced by the sociology of knowledge as explained and popularized by Peter Berger and Thomas Luckmann. See P. Berger \& T. Luckmann, The Social Construction of Reality: A Treatise IN THE SOCIOLOGY OF KNOWLEDGE (1967). According to their formulation, humans must provide a stable environment for their conduct. See id. at 59 . This environment is provided by the linguistic organization of phenomena. Thus, the apparent objectivity of the world is a "humanly produced, constructed objectivity." Id. at 60; see also B. BERnstein, Class, Codes and Control: Theoretical Studies Towards A Sociology of LANGUAGE 136-37 (2d rev. ed. 1974) (arguing that language is embedded in and defines social reality); Bidney, Myth, Symbolism, and Truth, in MYTH: A SYmposium 14 (T. Sebeok ed. 1965) ("[M]yth objectifies and organizes human hopes and fears . . . ."); Whorf, The Relation of Habitual Thought and Behaviour to Language, in Language in Thinking 123, 126-28 (P. Adams ed. 1973) (describing the relationship of language to culture and arguing that language and culture are dialectically shaped).

12 An example of such an approach is that known as "critical legal studies." For an introduction to the range of work represented by this approach, see THE Polrtics of LAw: A Progressive Gritique (D. Kairys ed. 1982) [hereinafter cited as PoliTics of Law]; Critical Legal Studies Symposium, 36 Stan. L. REv. 1 (1984). See also R. Unger, KNOWLEdGe AND Politics 63-103 (1975) (criticizing the liberal bases of modern legal thought). Approaches as different from critical legal studies as "legal philosophy" and "law and economics" also argue that the law fails to conform adequately to selected normative criteria. See, e.g., R. POSNER, ECONOMIC ANALYSIS OF LAw 1718 (2d ed. 1977) (observing that economics, by which the author means microeconomics, can play a reformative role in law). See generally M. TIGaR \& M. LEVy, LAW AND THE RISE OF CAPITALISM 230-41 (1977) (discussing the values underlying several schools of legal thought).

13 For a formulation of this approach in the context of legal scholarship, see Gordon, New Developments in Legal Theory, in PoLrrics of LAw, supra note 12, at 287-90 (describing law as one kind of intellectual-linguistic system building).

14 This is what is usually referred to as "legitimation." See, e.g., P. BERGER \& T. 
Like any set of world views, those encoded in legal opinions are continually in the process of being formed and reformed. ${ }^{15}$ Legal controversies represent the attempts of individuals and groups to reform the legal view of reality to conform to their interests. Each time a case is decided and a new opinion is issued, the legal world view is reformed in varying degree, depending upon the outcome of the case.

Legal opinions, by virtue of being continually contested, are similar to all other social constructions of reality. ${ }^{16}$ Unlike other forms of reality making, however, court opinions are sanctioned by the force of the state. A legal controversy is not merely a controversy about the construction of reality; it is also a struggle for the access to physical force granted to those whose version of reality is accepted. When a case is

LucKMANN, supra note 11, at 93 (describing legitimation as the ascription of cognitive validity to linguistically objectified meanings); J. HABERMAS, LEGITIMATION CRISIS 22 (T. McCarthy trans. 1975) (describing the "socially integrative" characteristic of ideology); M. TIGAR \& M. LEVy, supra note 12, at 279 (describing law as the crystallization of social relations); Gordon, supra note 13, at 288 (describing the integrative character of system building).

${ }^{10}$ See P. Berger \& T. Luckmann, supra note 11, at 61 ("[T]he relationship between man, the producer, and the social world, his product, is and remains a dialectical one."); M. TIGAR \& M. LEvy, supra note 12, at 288-89 (describing the process by which legal ideology crystallizes social and economic relations and then becomes an empty form, only to be recrystallized). This Comment is an extended investigation of the process of reforming legal world views in the narrow context of a single case. In conceiving the process of legal world building as dialectical, the Comment joins scholars who deny that legal ideology serves class interests in narrow, simple-minded ways. See, e.g., C. GeERTz, Ideology as a Cultural System, in The INTERPRETation of CulTURES: SELECTED EsSAYS 202 (1973) (arguing that a pure interest theory of ideology suffers from a too-muscular sociology and a too-anemic psychology). Rather, the Comment regards ideology as a process by which both the nature of reality and the relationships among the groups and classes that compose that reality are constantly being reformulated and objectified. See, e.g., Gordon, supra note 13, at 288 (observing that legal world views are necessarily believed by some of those whom they disserve as well as those whose interests they seem most obviously to serve). While the law inevitably serves the dominant classes better than the underclasses, it does so primarily by formulating favorable synthetic accounts of social reality, not by frankly coercing disbelievers.

${ }_{10}$ Perhaps the most intuitively obvious example of a social construction of reality is the concept of family. Human biology is identical everywhere, but no concept varies more widely from place to place, across time, and across cultures than that of family. See, e.g., G. Murdock, Social Structure 108-10 (1966) (summarizing cross-cultural differences in kinship terminology and the causes of such differences). The evolutionary nature of concepts of family is evident from our own history. Compare D. SchNeIder, American Kinship: A Cultural ACCOUnT 37 (1968) (The twentiethcentury American concept of family is preeminently nuclear and biological.) with $\mathrm{E}$. Morgan, The Puritan Family 150 (1966) (The seventeenth-century New England family extended beyond the bounds of the modern family.). That cultural concepts of family are contested is evident in recent case law. See, e.g., Moore v. City of East Cleveland, 431 U.S. 494, 498-99 (1977) (invalidating a city zoning ordinance that required a family to exclude certain blood relatives). To the extent that a court opinion depends on, adduces, or invokes culturally determined beliefs, such as those involving the family, the opinion is necessarily part of an evolving intellectual construction of social reality. 
decided, one party wins and gets real power. Over time the legal reality of the opinion becomes autonomous-separate from the reality in which it originated. This now autonomous linguistic reality becomes a part of our collective stock of knowledge about the social world. The opinion comes to seem true and to control our ability to shape our lives.

As this model suggests, to ignore the interplay of social forces that produces an opinion is to miss the meaning of that opinion for those whose lives the court's decision will govern. The full construction of the decision's meaning requires a reconstruction of those forces. To understand a judicial opinion, we must seek to understand not only the reality the opinion endorses but also the reality it rejects; we must seek to understand not only the issue between the parties but also the larger social issues and forces those parties represent.

This Comment tries to articulate the meaning of Hood by placing the state legislation and the Supreme Court opinions in their appropriate historical, social, and economic contexts and exploring in some detail the world the Court rejected in order to illuminate the world it accepted. Part I presents the historical background and economic theory of the New York Agriculture and Markets Law. Part II analyzes the logic of both Justice Jackson's invalidation of that law and the dissenters' arguments that the law must stand. Part III examines the broad social and historical contexts of the Hood opinions in order to clarify the vision of political economy that Hood endorsed. Taken together, these excursions into the several contexts of Hood provide a rich, albeit partial, sense of the Court's choice between, on the one hand, the traditional world of local, rural culture, and on the other, the modern world of national, industrial culture.

\section{The Historical Gontext of Depression Farm Legislation: An Agricultural Grisis aNd NEW YORK'S RESOLUTION}

\section{A. Depression on the Farm}

After almost a century of steady migration from farm to town and city, ${ }^{17}$ and after forty years of nearly unrelieved agricultural reces-

17 The migration of people from country to city and the industrialization of a once predominantly rural economy are axioms of our history. The beginnings of this transformation of American life lie in the first quarter of the nineteenth century. See, e.g., J. HenRetTa, The Evolution of American Society 1700-1815, at 204 table 6.3 (1973) (proportion of agricultural workers dropped from $82.6 \%$ in 1800 to $53.2 \%$ in 1860) (citing David, The Growth of Real Product in the United States Before 1840, 27 J. Econ. Hist. 151, 166 table 4, 184 table 8 (1967)); L. TweETEN, Foundations of FARM Policy 126 table 5.1 (1970) (The proportion of workers in agriculture dropped 


\section{sion, ${ }^{18}$ the arrival of the twentieth century ushered in the "farmer's}

from $83.5 \%$ in 1800 to $64 \%$ in 1840 , to $21.5 \%$ in 1930 , and to $9.5 \%$ in 1960 .).

18 As the author of a standard history of American farming puts it, between 1867 and 1898 farmers "endured nearly continuous depression." J. SCHLEBECKER, Whereby We Thrive: A History of AMERICAN Farming 1607-1972, at 161 (1975). For other short, readable narrative histories of agriculture in these years, see W. Cochrane, The Development of American Agriculture: A Historical ANalysis 78-98 (1979); G. Fite, American Farmers: The New Minority 1-19 (1981).

The sustained agrarian crises of the last quarter of the nineteenth century produced Populism, the first self-consciously agrarian political movement. See, e.g., J. Hicks, The Populist Revolt: A History of the Farmer's Alliance and the PeOPle's PARTY 95 (1931) (summarizing the sources of agrarian discontent). Following John Hicks, Norman Pollock found in Populism the basis for a sweeping critique of the emerging industrial order. See N. Pollock, The Populist Response to INDUSTRIAL AMERICA 25 (1962) ("Populism criticized industrial America for creating not only poverty, but a new man-alienated man."). More recently, in his brilliant study of upcountry Georgia, Steven Hahn has developed a more sophisticated yet still-similar view of the cognitive disjunction that industrialization wrought in American thinking. See S. Hahn, The Roots of Southern Populism 282 (1982) ("To the hegemony of the marketplace, Populism counterposed the vision of a producers' commonwealth ....".).

Some understanding of the flowering of agrarian discontent in these years is important for an understanding of the issues in Hood. Drawing upon the ancient English rhetoric of the independent yeoman, the farmer's movement began transforming that rhetoric from a normative vision of the good society into a minority political program. See, e.g., R. HofstadTER, The AGE OF REFORM 23-26 (1958) (describing the process by which the myth of the yeoman was incorporated into American politics); see also J. CREvecoevr, LeTters From AN AMERICAN FARMER 61 (1782 \& photo. reprint 1968) (defining an American as a "possessor of the soil").

As the nineteenth century wore on, this vision of a predominantly agricultural society of yeomen became increasingly divorced from reality, but the vision endured. See, e.g., G. FITE, supra, at 244 ("Many citizens are still struggling in the early 1980's to reconcile modernized agriculture and its effects on rural America with emotions and traditions that lie deep in pre-industrial farming."); R. NYE, MIdWestern Progressive Politics: A Historical Study of its ORIgins and Developments 18701958 , at 15 (1959) ("The primary problem of America after 1865 was to resolve the clash between the old ideals of agrarian democracy and the new industrialism . . . ."); J. Shover, First Majority $\triangle$ Last Minority: The Transforming of Rural LIFE IN AMERICA 12 (1976) (citing polls that indicated that in 1953, 1966, and 1970 a majority of Americans preferred country to city life and concluding that " $[\mathrm{t}] \mathrm{he}$ agrarian past lingers with peculiar tenacity in popular thought and culture").

The constellation of ideas that made up the Populist vision of a predominantly agrarian America has been a major influence on American farm policy throughout the twentieth century, producing legislation such as that represented by article 21. See, e.g., G. Gramer \& C. Jensen, Agricultural Economics and Agribusiness 287 (3d ed. 1985) (basic-level text in agricultural economics discussing effects of "farm values" on farm policy); Flinn \& Johnson, Agrarianism Among Wisconsin Farmers, 39 RURAL Soc. 187, 187 (1974) (basic discussion of the history of American agrarian ideology). In a nutshell, agrarianism provided an alternative to Justice Jackson's ebullient vision of an expanding, market-oriented society. See infra text accompanying notes 149-68. While these two social visions have sometimes coincided, see R. HoFSTADTER, supra, at 46-47 (arguing that agrarianism was not always at odds with market-oriented behavior), they came into sharp conflict in Hood. This Comment argues that, considered as a cultural event, the Hood case presented the Court with a sharp contrast between the ideology of agrarianism and that of industrialism. In deciding that the 
golden age."18 For two decades, the long, slow transformation of America from a nation of yeomen to one of workers seemed to have halted. When the 1920's arrived, almost a third of our population still lived on 6.5 million farms. ${ }^{20}$

In the autumn of 1920 , however, farm prices dropped sharply in the face of post-war recession. ${ }^{21}$ Then, between 1929 and 1936, in the throes of a world-wide depression, the bottom fell from beneath America's farmers as prices declined by a full two-thirds in seven years. ${ }^{22}$ In the next decade another million farmers abandoned agricul-

agrarian vision was not a legitimate social vision for a state to pursue, Hood rejected a deeply rooted, major strain in American social thought and provided a part of the legal context for the subsequent decline in the vitality of local rural cultures.

19 With the possible exception of the period from 1945 to 1948 , the first decades of the twentieth century were the best years of the century for farmers. See, e.g., W. Cochrane, Farm Prices: MYth and Reality 12 (1958) (indexes of farm prices from 1826 to 1956); G. FrTE, supra note 18, at 16-17 (briefly describing the high farm prices of the early twentieth century and their effects); see also M. BENEDICT, FARM Policies OF THE UNITED STATes 1790-1950, at 450 (1953) (On an index in which prices from 1910 to 1914 were set equal to 100 , prices rose to 116 in 1941 and to 180 in 1945, and "an enormous further increase was to be recorded in 1946,1947, and 1948."); G. FITE, supra note 18, at 87 (describing succinctly the prosperity of the 1940's). At the depths of the Depression, policymakers took the years 1909 to 1914 as the touchstone of a healthy agricultural economy. The Soil Conservation and Domestic Allotment Act of 1936, for example, attempted to restore "the ratio between the purchasing power of the net income per person on farms and that of the income per person not on farms that prevailed during the five year period August 1909-July 1914." Pub. L. No. 74-461, $\S 7(a), 49$ Stat. 1148, 1148 (codified as amended at 16 U.S.C. $§ 590 \mathrm{~g}(1982))$.

20 See G. GRAmer \& C. Jensen, supra note 18, at 29 table 2.6 (proportion of population on farms); see also G. FrTE, supra note 18, at 101 (chart showing trends in American farming, 1935-1980); J. SHOVER, supra note 18, at 6 (net migration from farm population, 1920-1974); USDA, A TIME To Choose: Summary RePort ON THE STRUCTURE OF AGRICULTURE 42 (1981) (graph showing number of farms, 19201980).

21 See W. Cochrane, supra note 19, at 18 (describing the fall in prices in 1920 as a "disaster" for farmers); id. at 12, 14 (indexes of farm prices, 1826-1956); G. Frre, supra note 18, at 34-37 (chronicling the precipitous drop in prices and farm incomes in the early years of the 1920's); L. TWEETEN, supra note 17, at 73 ("The index of farm prices fell from 211 in 1920 to 124 in 1921 [1910-1914=100] and was never over 156 during the remainder of the 1920's.").

${ }^{22}$ See G. FITE, supra note 18, at 51 (estimating the price drop in agricultural products at $63 \%$ for the years 1929-1933); L. TWEETEN, supra note 17, at 77 (The farm price index $(1910-1914=100)$ fell to 65 in 1932.). Prices tended to move downward rapidly in these years, and everywhere the story was equally dismal. See, e.g., W. Cochrane, supra note 19, at 14 figure 2; R. Ingalls, Herbert H. Lehman and New York's LitTle New Deal 151 (1975) (New York milk prices, which had held up well during the first years of the Depression, declined by $38 \%$ in two months in the winter of 1931-1932.); STAFF OF UNIVERSITY OF IOWA, A GenTURY OF FARMING IN IowA, 1846-1946, at 347 (1946) (Gross farm income in Iowa dropped from $\$ 830$ million in 1929 to $\$ 317$ million in 1932.). See generally G. FrTE, supra note 18, at 49 (describing "new and shocking levels of want and destitution beyond anything previously known"). 
ture, beginning what one historian has called one of the largest migrations in human history-the migration of Americans from country to city. ${ }^{23}$

The suffering on America's farms was real; its portrayal in scholarly and popular literature shocked the country. ${ }^{24}$ Equally real was the shock of recognition with which the nation began to understand that it was no longer a nation of farmers. These personal-economic and national-cultural crises precipitated an intensely creative era in American politics. Southern tenant farmers flirted with unionism; ${ }^{25}$ midwestern farmers flirted with socialism. ${ }^{28}$ In the Congress, the farm problem oc-

${ }^{23}$ See J. SHOVER, supra note 18, at 6 (estimating that the farm population dropped by 1.2 million between 1920 and 1930). Farm demography of the 1920's and the Depression years is difficult to analyze. Demographers disagree about how to define the terms farm, farmer, urban, and rural. See, e.g., W. CochraNe, supra note 20, at 23-24 (distinguishing between commercial and residential farms); USDA, supra note 19, at 46-50 (discussing various categories of farm). Thus, estimates vary with the definitions used. More important, perhaps, large numbers of the urban unemployed returned to the countryside during the Depression. See J. SHover, supra note 18, at 6 . Consequently, an unspectacular numerical decline masks the beginnings of one of the largest population movements in human history. When World War II spurred economic opportunities, farmers left the countryside in droves. See id. at 4. The proportion of farmers in the population declined from about $25 \%$ in 1935 to about $15 \%$ in 1950. See G. Fire, supra note 18, at 101. In all, at least thirty million people left the American countryside in the years between 1930 and 1970. See J. SHover, supra note 18, at 4 .

24 The literature is so vast as to defy fair summary. It is fair to say, however, that it was during this time that America first realized that it had been fragmented into separate rural and urban cultures, and that the rural poor belonged to a world so vastly different from the world of the urban elite as to merit close artistic and scholarly attention. Among the better-known works of the era that have retained their power to shock the reader are J. Agee \& W. Evans, Let Us Now Praise Famous Men (1939) (photodocumentary account of three Alabama tenant farm families); D. LANGE \& P. TAYLOR, AN AMERICAN Exodus (1969) (collecting some of the best known of the five hundred thousand photographs taken of rural Americans by Farm Security Administration photographers); A. MAcLeISH, LAND OF THE FREE (1938) (vituperative poetic account of environmental destruction during the Depression); J. STEINBECK, THE GRAPES OF WRATH (1940).

${ }^{25}$ See, e.g., D. Grubes, Cry From Cotton: The Southern Tenant FARMER's UNION AND THE NEW DEAL (1971) (tracing the history and ultimate failure of Southern sharecroppers' unions during the 1930's); T. ROSENGARTEN, ALL God's DANGers: The LIFE OF NATE Shaw (1974) (oral biography of one leader of the Alabama Sharecroppers' Union); Wise \& Thrasher, The Southern Tenant Farmers' Union, in Working LIVEs: The SOUTHERN ExPOSURE History OF LABOR IN THE SOUTH 120, 120-42 (M. Miller ed. 1980) (presenting six first-person accounts of the Southern Tenant Farmers' Union).

${ }^{28}$ See, e.g., Dyson, The Farmer and the Left: The Influence of Radical Farm Organizations, in Farmers, Bureaucrats, and Middlemen: Historical PerSPECTIVes ON AMERICAN Agriculture 80-99 (T. Peterson ed. 1980) (describing the success of the Socialist Party in rural America in the early twentieth century and of "radical farm organizations" during the agricultural depression of the 1920's and 1930's); Saloutos \& Hicks, The Farm Strike, in Patterns and Perspectives in Iowa Hrstory 359 (D. Schwieder ed. 1973) (describing events in Iowa leading to the 
cupied near-center stage throughout the 1920's, ${ }^{27}$ and in state houses across the land, legislators grappled with the complex relationships among economics, politics, and society as they attempted to respond to crisis. $^{28}$

In coming to grips with the agricultural crisis of the Depression years, legislators, economists, sociologists, and cultural critics began to discern, if but vaguely, the large contours of the modern American "farm problem." They realized that the distinctive characteristic of American agriculture was its ability consistently to outproduce demand. ${ }^{29}$ Thus, farm prices were low and farm incomes inade-

farm strike of 1931).

${ }^{27}$ For succinct descriptions of the federal legislative response to the crisis of the 1920's, see G. FITE, supra note 18, at 41-48; L. TWEETEN, supra note 17, at 301 . In brief, five agricultural bills were introduced into Congress in 1924 and 1925, precipitating five years of debate. See M. BENEDICT, supra note 19, at 212. Two McNaryHaugen bills passed Congress, H.R. "12,687, S. 3555, 70th Cong., 1st Sess. (1928); H.R. 15,474, S. 4808, 69th Cong., 2d Sess. (1927), only to be vetoed by President Coolidge. See M. BEnEDICT, supra note 19, at 227, 229. Finally, in 1929, Congress passed and President Hoover signed into law the Agricultural Marketing Act, Pub. L. No. $71-10,46$ Stat. 11 (1929) (codified as amended in scattered sections of 12 U.S.C.), the first national legislative attempt to cure the persistent problems of farm surplus and inadequate farm incomes. See G. FITE, supra note 18 , at 49 . See generally M. BENEDICT, supra note 19, at 207-38 (analyzing in more detail federal farm policy debates of the years 1924 to 1929); id. at 200 (describing the activities of the 1921 Congressional Joint Commission of Agricultural Inquiry); $i d$. at 239-40 (describing the operation of the Agricultural Marketing Act of 1929).

${ }^{28}$ There is no comprehensive scholarly survey of state responses to the Depression. Robert Ingalls does, however, provide a summary of the New Deal in New York. See R. INGaLls, supra note 22. For Ingalls' description of New York's agricultural legislation, see $i d$ : at 148-81. In the midwest, several states passed relief acts in response to farm problems and farmer discontent. See, e.g., T. BLEGEN, Minnesota: A History OF THE STATE 523-36 (1963) (recounting how the Farmer-Labor party gained control of state government); J. Madison, Indiana Through Tradition and Change: A History of the Hoosier State and its People, 1920-1945, at 176 (1982) (describing the successful efforts of the Indiana Farm Bureau to change property-tax laws); J. OLSON, A HistoRY OF NEBRASKA 296-97 (1966) (describing the state legislature as unsuccessfully wrestling with the problems of the Depression in early 1933); L. SAGE, A HISTORY OF IOWA 291-302 (1974) (tax relief measure in Iowa). For a summary of state efforts to regulate the dairy industry, see J. BLACK, THE DAIRY INDUSTRY AND THE AAA 311 (1935).

29 One agricultural historian describes "excess productive capacity" as a chronic problem of agriculture in the years from 1939 to 1970. W. CochraNE, supra note 18, at 137-40; see also G. CRAMER \& C. JENSEN, supra note 18, at 291-92 (discussing the large economic impact of excess production); G. FITE, supra note 18, at 73 ("Increased farm output ... posed a dangerous threat to the goals of price and income parity established by New Deal planners and Congress [in the 1930's].'); L. TwEeTEN, supra note 17, at 155-56 (discussing the problem of excess capacity and estimating excess at between five and ten percent of total production between 1956 and 1966); Bitter Harvest, NewsweEk, Feb. 18, 1985, at 52, 56-58 (discussing the current oversupply of many farm products).

Most twentieth-century agricultural policy can be understood as an attempt to deal with the problem of excess capacity. See L. TWEETEN, supra note 17, at 155-56; 
quate. ${ }^{30}$ High labor costs coupled with low prices created strong incentives to substitute capital for labor in farm production. ${ }^{31}$ Average rates

see also M. BENEDICT, supra note 19 , at 302-15 (describing and analyzing the attempts made in the Agricultural Adjustment Act of 1933, Pub. L. No. 73-10, 48 Stat. 31 (codified as amended at 7 U.S.C. $\$ \S 601-624(1982)$ ), to reduce excess supply by limiting acreages and raising exports); id. at 362 (setting forth the provisions of the Bankhead-Jones Farm Tenant Act of 1922, Pub. L. No. 75-210, 50 Stat. 522 (codified as amended in scattered sections of 7 U.S.C.), in which Congress sought to aid poor farmers through government purchases of "sub-marginal lands"); W. CochraNE, supra note 18, at 288 (describing the acreage limitations in the Food and Agriculture Act of 1965, Pub. L. 89-321, 79 Stat. 1187 (codified as amended in scattered sections of 7 U.S.C.)); G. FITE, supra note 18, at 48 (describing the Agricultural Marketing Act of 1929, Pub. L. No. 71-10, 46 Stat. 11 (codified as amended in scattered sections of 12 U.S.C.), as an attempt to control excess supply).

The principal device that government has used to try to limit production has been a system of voluntary acreage limitations. In brief, farmers have been paid for not using some of their land. See, e.g., M. BENEDICT, supra note 19, at 303-04, 375-78 (describing the acreage limitations of the Agricultural Adjustment Act of 1933, Pub. L. No. 7310 , 48 Stat. 31 (codified as amended at 7 U.S.C. $\$ \$ 601-624(1982)$ ), and the Agricultural Adjustment Act of 1938, Pub. L. No. $75-430,52$ Stat. 31 (codified as amended in scattered sections of 7 U.S.C.)). The system of voluntary acreage limitations, however, has backfired dismally. Farmers have responded by retiring their worst land from production and by increasing their use of fertilizer and the quality of their machinery inputs. See, e.g., W. Cochrane, supra note 18, at 128 table 7.1 (demonstrating that while wheat yields increased about $25 \%$ between 1870 and 1950 , they more than doubled between 1950 and 1970); J. SCHLEBECKER, supra note 18, at 243 (noting that wheat production increased between 1937 and 1944 even though wheat acreage was reduced by $25 \%$ during that same period).

so "Low" is, of course, a relative term. Here and throughout this Comment, "low" refers to prices that are too low to permit a number of farmers determined to be culturally desirable to make a living from farming. See L. TwEETEN, supra note 17, at 155 (defining the related problem of excess capacity as the "surplus of production capacity over market utilization at socially acceptable prices"). Within these definitional constraints, agricultural writers agree that farm prices have been low for most of the last century. See, e.g., G. CRAMER \& C. JENSEN, supra note 18, at 291 (Agricultural prices and incomes have been relatively low in the twentieth century.); J. SHover, supra note 18, at 7 (Farmers' per capita income is consistently lower than nonfarmers'.); L. TWEETEN, supra note 17, at 163-65 (analyzing the problem of low farm income).

31 See, e.g., W. Cochrane, supra note 18, at 322-23 (describing the dramatic change in agriculture between 1900 and 1975 that resulted from the substitution of machines for expensive labor); see also id. at 205 table 10.2 (Labor as a proportion of all farm inputs declined from $65 \%$ in 1870 to $16 \%$ in 1976.); G. FrTE, supra note 18, at 79 ("The substitution of capital for labor [between 1920 and 1940] was producing much of the change on American farms.").

As these long-run analyses suggest, the process of capital substitution has its roots in the nineteenth century. See, e.g., id. at 11-19 (describing nineteenth-century farm life). The proportionately largest changes, however, have occurred in the past fifty years. See, e.g., id. at 69-70 ("The most important development in American agriculture in the 1920's and the 1930's was the gradual shift in some parts of the country from horses and mules to tractor power."); J. SCHLEBECKER, supra note 18, at 252 table 22.1 (showing that as late as 1936 more than half of all farms used horsepower exclusively); see also W. Cochrane, supra note 18, at 130 table 7.2 (Purchased farm inputs more than doubled in constant dollars between 1934 and 1970.); id. at 128 table 7.1 (The largest proportional increase in wheat and corn yields between 1870 and 1970 
of profit per unit of input declined steadily, ${ }^{32}$ creating additional incentives to increase both the size and intensity of farming operations. In short, American farming was an intensely and endemically competitive business, characterized by low and declining profitability. And declining profitability was steadily driving farmers out of business.

A detached observer might have regarded the steady decline in the farm population as the necessary result of the social and economic organization of American life, but such an observer could rarely be found. Farmers occupied a special place in American history and in the American imagination; farmers were perceived as a distinct social group, not merely as laborers. ${ }^{33}$ To policymakers, whose perceptions were constrained by a set of cultural assumptions about the farmers' role in American society, inadequate farm incomes became a problem to be remedied, not an incentive for farmers to change jobs. ${ }^{34}$

occurred during the last 20 years of that period.); $i d$. at 132 (The number of farms declined by $55 \%$ between 1935 and 1970.); id. at 134 (describing changes in the structure of the farm between 1933 and 1970 as "radical"); J. SHOVER, supra note 18, at 115 (arguing that farming in 1920 was probably more like it was in 1720 than it was in 1970).

${ }^{32}$ See P. SAmuelson, Economics 21-25 (11th ed. 1980) (orthodox microeconomic presentation of declining marginal returns); Goss, Rodefeld \& Buttel, The Political Economy of Class Structure in U.S. Agriculture: A Theoretical Outline, in The RuRal Sociology of THe Advanced Societies 83, 88 (1980) (summarizing Marx's formulation of the tendency of the average rate of profit to decline with the substitution of capital for labor). In practical terms, the immediate effect of the declining rate of profit is that the product of an acre of land and one person's labor will buy relatively less over time. In consequence, access to capital for the purchase of land and technology becomes a critical determinant of farm survival. See, e.g., W. Cochrane, supra note 18, at 133, 352 (Only the technological vanguard of farmers has profited in the mid-twentieth century.). Owners of larger farms have considerable advantages in obtaining credit and federal aid, and they are likely to have better access to information. See Bitter Harvest, supra note 29, at 56. But of. Easterbrook, Making Sense of Agriculture, ATL. Montrly, July 1985, at 63, 64 (Smaller farms are more likely to be enrolled in federal subsidy programs than large farms.). More important, perhaps, the development of agricultural technology has vastly transformed the culture of agriculture, and it is difficult to argue that the modern farm-community region, with its vast and widely separated farms, bears any close sociological resemblance to the rural communities of even the recent past. See infra notes 65, 158-59 and accompanying text.

${ }^{3 s}$ See G. FITE, supra note 18, at 130 ("The prospect of a continuing decline in the number of family farms struck at some very deeply held American emotions and beliefs. Indeed, the family farm was at the center of the agrarian tradition, which claimed that agriculture provided a superior way of life . . ..").

st See id. at 122-23 ("Most Americans, however, did not favor government policies that would accelerate the decline of the farm population. Such a policy ran counter to the deep feelings held by many people that there was something good about life on the land, both for individuals and for the nation."); id. at 131 (describing bipartisan support in the 1940's and 1950's for treating the family farm as a cultural artifact).

One might of course argue that the number of farmers should be determined by market forces. See, e.g., id. at 76 (discussing the increasing national awareness in the 1940 's that there was a surplus farm population and that traditional ideals of the role of farmers in American society might have to change); id. at 166-67 (describing the 
These assumptions were embedded in the ancient rhetoric of the independent yeoman, which equated personal and civic virtue with personal independence and land ownership, and the strength of the nation and the vitality of democratic processes with the size and strength of the independent farm population. ${ }^{35}$ Moreover, large numbers of Americans were but one generation from the land, and their understanding of proper social organization was still a product of rural culture. ${ }^{36}$

This complex of perceptions represented a substantial commitment to the Jeffersonian ideal of a nation of small-scale communities-based on the wide distribution of land and characterized by participatory democracy - and to the proposition that America should continue to provide room for a substantial and vigorous farm population. ${ }^{37}$ In the ser-

farm interests' enormous cry of opposition following a 1962 study by the Committee for Economic Development that recommended policies that would reduce the number of farmers); P. SAMUELSON, supra note 32, at 384 (describing the problem of agriculture as a problem of surplus population); Easterbrook, supra note 32, at 78 ("Eventually Congress will have to face the fact that there are too many farmers.").

This argument, however, has rarely been made. For almost six decades since President Coolidge's veto of the McNary-Haugen Bills in 1927 and 1928, see supra note 27 , national farm policy has been based in part on the assumption that the market does not produce as many farmers as the culture as a whole desires. See W. Cochrane, supra note 18 , at $290-92$.

ss A full examination of the effect on farm policy of the notion that America is and ought to be a nation of farmers is beyond the scope of this Comment. Raymond Williams has observed that the concept of an ideal, but now vanished, rural past is frequently used as the basis for critiques of modernism and that such critiques have placed the decisive point of the disappearance of this ideal in every century since the sixteenth. See R. Williams, The Country and the CrTy 35-36, 290-91 (1973). By focusing on the process by which the Hood Court's rhetoric was formed, this Comment seeks to avoid the romantic fallacy, identified by Williams, of uncritically preferring the past to the present. Although the Comment is informed by the notion that the ideal of Jeffersonian agrarianism, see infra note 37 , may be preferable to the ideal of economic growth, it makes no claim that the world left behind by Hood was a better world than that presaged by Hood. The claim, rather, is that the transition from one world to the other was one of profound significance.

${ }^{36}$ See supra note 23 and accompanying text; see also K. Barry, Theme Song-1936: GIVE Us BACK OUR INDEPENDENCE 15 (1936) ("The American Revolution was a triumph of farmers . . . ."); E. BenSON, FreEdom To FaRM 109 (1960) ("[The country] is a good place to teach the basic virtues that have helped to build this nation."); Businessman's Commission ON Agriculture, The Condition OF AGRICULTURE IN THE UNITED STATES AND MEASURES FOR ITS IMPROVEMENT 18 (1927) ("[The farmer's] is a proud heritage."); G. FITE, supra note 18, at 18 ("The farmer represents a peculiarly high type of American citizenship." ") (quoting Theodore Roosevelt); T. JefFerson, Notes on the State of Virginia, in ThOMAS JefFerson: WRITINGs 290 (M. Peterson ed. 1984) ("Those who labour in the earth are the chosen people of God ....."); J. Shover, supra note 18, at 12 (describing a public opinion poll taken in the mid-1950's showing that farm life represented the ideal of a majority of Americans).

${ }^{37}$ Throughout this Comment, the term "Jeffersonian ideal" stands for the notion of relatively small-scale, participatory democracy based on the relatively wide distribution of landed property. While such usage does not pretend to be a full or accurate portrayal of Jefferson's ideal, it is thoroughly grounded in Jefferson's thought. See, e.g., 
vice of this ideal, Depression-era legislators sought to design programs that would redress inadequate farm incomes, keep farmers in business, and allow rural culture to survive.

\section{B. Section 258-c of Article 21}

Article 21 of the New York Agriculture and Markets Law ${ }^{38}$ was a local response to the acute crisis that the Depression precipitated in New York dairy farming. ${ }^{3 \theta}$ By the spring of 1932, it was obvious that the federal Agriculture Marketing Act of 1929 had failed to relieve farmers of the burden of the Depression. ${ }^{40}$ In New York, the nation's second largest producer of milk products, many farmers neared ruin as dairy prices plummeted faster than other farm prices. ${ }^{11}$

In March of 1932 the New York Legislature created a special joint committee to investigate the causes of the decline of the price of milk. ${ }^{42}$ After hearings that lasted nearly a year and produced more than 2000 pages of testimony, the committee concluded that an acute emergency existed in the state dairy industry and that this emergency threatened the health of the inhabitants, the survival of the farm population, and the economic stability of the state and its local governments. ${ }^{43}$ In response, the legislature enacted article 21 , an omnibus

A. Koch, The Philosophy of Thomas Jefferson 164-65 (1957) (describing Jefferson's belief in the necessity that republics be small); $i d$. at 172-73 (comparing Jefferson's love for agriculture with his distrust of manufacturing); C. WILTSE, THE JEFFERSonian Tradition In AMERICan Democracy 137-38 (1935) (describing Jefferson's view that unequal division of property should be minimized); $i d$. at 147 ("IJefferson] felt unmistakably the unrest and uneasiness preceding the birth pangs of a capitalistic industrialism. ... His ideal would have been a society built upon ... landowners .....").

${ }^{38}$ Act of Mar. 30, 1934, ch. 126, 1934 N.Y. Laws 564 (codified as amended at N.Y. AGRIC. \& MkTS. LAW §§ 252 to 258-r (McKinney 1972 \& Supp. 1985)).

${ }^{39}$ See R. INGALLS, supra note 22 , at $152-52$ (summarizing the effects of the Depression, with particular reference to the New York dairy industry). In brief, local dairy prices held up well through the 1920's and into the first years of the Depression. By 1934, however, New York milk prices had fallen by more than $50 \%$ to levels $34 \%$ below the general price level. In March 1933, dairy farmers struck. In August, they rioted. See id. at 151, 155; see also G. FITE, supra note 18, at 49 (providing a short, readable history of some of the effects of the Depression by summarizing and excerpting from the letters of farmers).

${ }_{10}$ See G. FITE, supra note 18, at 48 (discussing the Agriculture Marketing Act of 1929, Pub. L. No. 71-10, 46 Stat. 11 (codified as amended in scattered sections of 12 U.S.C.)). See generally M. BENEDICT, supra note 19, at 247-67 (discussing the effect of the Depression on agriculture and attempts to alleviate it).

4 See R. INGalls, supra note 22, at 151; see also USDA, Agricultural STATISTICs 1946, at 388 table 505 (showing that New York ranked second nationally in gross dollar value of dairy products).

${ }^{42}$ See Nebbia v. New York, 291 U.S. 502, 516 (1934); R. INGalls, supra note 22, at 151-52 (summarizing the formation of the joint committee and its work).

${ }^{43}$ See Nebbia v. New York, 291 U.S. 502, 516 (1934); see also id. at 518 n.2 
milk control act, and article $21 \mathrm{~A}$, an emergency price control act. ${ }^{44}$

In their first forms, articles 21 and $21 \mathrm{~A}$ empowered the State Commissioner of Agriculture to set farm production quotas, ${ }^{45}$ minimum prices for farm products, ${ }^{46}$ minimum and maximum retail prices, ${ }^{47}$ and minimum and maximum charges for the handling and processing of milk and milk products. ${ }^{48}$ Together, these sweeping powers allowed the Commissioner to control both the costs and revenues of milk producers and processors and, therefore, to control the structure of New York dairying and milk marketing. ${ }^{48}$

(setting forth provisions of the Act of Apr. 10, 1933, ch. 158, $\S 300,1933$ N.Y. Laws 558,559 , repealed by Act of May 7, 1934, ch. 319, 1934 N.Y. Laws 849).

44 In 1933, the New York Legislature enacted article 25. Act of Apr. 10, 1933, ch. 158, 1933 N.Y. Laws 558, repealed by Act of May 7, 1934, ch. 319, 1934 N.Y. Laws 849. This was a one-year emergency measure that controlled entirely the production, distribution, and sale of milk products. When article 25 expired, it was replaced by articles 21 and 21A. Act of Mar. 30, 1934, ch. 126, 1934 N.Y. Laws 564 (codified as amended at N.Y AGRIC. \& MKTS. LAW $\S 252$ to 258-r (McKinney 1972 \& Supp. 1985)); see also R. INGALLS, supra note 22, at 152-54, 158-59 (tracing the history of the New York legislation).

t5 Act of Mar. 30, 1934, ch. 126, § 258-m(1)(a), 1934 N.Y. Laws 564, 575-76, repealed by Act of June 3, 1937, ch. 876, 1937 N.Y. Laws 1977.

48 Id.

17 Id. § 258-m(1)(b), 1934 N.Y. Laws at 575-76, repealed by Act of June 3, 1977 , ch. 876,1937 N.Y. Laws 1977.

${ }_{48} I d . \S 258-\mathrm{m}(1)(\mathrm{c}), 1934$ N.Y. Laws at 575-76, repealed by Act of June 3, 1937, ch. 876, 1937 N.Y. Laws 1977.

48 The power to set minimum prices allowed the Commissioner to determine the costs that a farm could incur without going out of business. At any price, the last surviving farm will be that farm whose average per unit costs are equal to its average per unit returns. See G. Cramer \& C. Jensen, supra note 18, at 143-45 \& figures 6$4,6-5,6-6$ (illustrating and discussing the basic relationship between costs, prices, and profits). In other words, no business can long survive if its per unit costs of production exceed the selling price of the relevant unit. Thus, the minimum price determines the maximum cost that an ongoing business will be able to incur. See id. at 297 figure 12-4 (illustrating the economic effect of maintaining price levels above the equilibrium price).

In theory, a system of minimum prices might be used to influence the development of rural culture. With perfect information, the body entrusted with setting the minimum could ascertain the culturally desirable number of farmers and the per unit costs of that number's least efficient producer. The minimum price would then be set equal to these costs. As minimum prices have historically been set, however, their effectiveness in preserving small farms has been far more modest in practice than it might have been in theory. There are a number of reasons for this limited effectiveness. First, minimum prices have usually been set at a level below the producers' median operating cost. See M. BENEDICT, supra note 19, at 450, 455-57; L. TwEETEN, supra note 17, at 304. Thus, half or more of all producers, including many small farmers, have been unable to cover their costs when selling at the minimum price level. Second, legislators and administrators apparently have never attempted to reach agreement on the culturally desirable number of farmers. Rather, minimum prices have usually been tied to the average price of agricultural commodities during the preceding 36-month period. See L. TWEETEN, supra note 17, at 309; USDA, supra note 20, at 58-60. Third, any benefits that do result from minimum prices may be capitalized in land values. See W. CochRANE, supra note 18, at 394; G. CRAMER \& C. JENSEN, supra note 18, at 303. 
At its inception, then, article 21 was grounded in the recognition that only full control over production, processing, and distribution allowed control over the organization of agriculture. ${ }^{50}$ In the decade

Finally, while minimum prices may have aided some farmers, the farmers most in need of assistance-those operating small farms-have benefitted least from these programs. Minimum prices have generally been supported either by payments to producers for not producing a particular crop or by government purchases of surplus commodities. See M. BenEdICT, supra note 19, at 276, 303; see also supra note 29 (discussing the use of voluntary acreage limitations). Neither of these forms of price support has been limited to smaller farmers. See USDA, supra note 20, at 102, 116. In general, small farmers cannot take advantage of developments in agricultural technology as rapidly as their larger competitors. As a result, the substantial improvements in farm technology that have taken place in the twentieth century may have lowered average operating costs in the industry while improving relatively little the position of small farmers. To the extent that average industry costs are used in setting minimum prices, technological development actually may have exacerbated the plight of the small farmer. In any event, the largest farmers have generally captured the largest portion of price supports, and some economists have argued that only relatively large farmers have been helped by minimum prices. See J. Shover, supra note 18, at 177; L. TwEeteN, supra note 17 , at 318 table 10.4 .

Minimum prices may have smoothed out some swings in commodity prices, kept some farmers in business who otherwise would have failed, and eased the transition of farmers out of agriculture. See W. CochraNe, supra note 18, at 384; G. CRAMER \& C. JENSEN, supra note 18, at 304 . But they have failed to halt the prevailing trend toward increasing concentration of farm ownership. See infra text accompanying notes 56-58. Given these limitations, the quota provisions of section 258 were an important complement to its minimum price provisions. The imposition of a quota would have prevented the generation of huge farm surpluses. More important, in the technological environment of the twentieth century, the judicious use of different price levels for surplus and quota products would have affected the nature of technological change. By setting lower prices for surplus milk, the Commissioner of Agriculture could have prevented farmers from adopting technology that would increase output and channel technological innovation toward producing the same volume of output more cheaply. For the reasons more particularly detailed in the preceding paragraphs, the absence of such quota provisions has fatally hampered the effectiveness of most mid-twentieth-century agricultural legislation.

so What is quite remarkable about articles 21 and $21 \mathrm{~A}$ is that they permitted the Commissioner of Agriculture to control every relevant variable in the production, distribution, and sale of agricultural commodities. In short, with adequate information, they could have worked. They present clearly, therefore, the essential conundrum of the "farm problem": namely, that if we want to preserve a substantial number of small farmers, then we must have a managed and planned economy. We cannot equitably limit farms' production without also limiting other economic activity. In the absence of such limits, the structure of the market operates ineluctably to diminish the number of farmers each year. See G. FITE, supra note 18, at 77 ("To have changed or retarded the course of American farming . . . on the eve of World War II . . . would have meant substituting elaborate government planning [for] advancing agricultural technology and organization, and private choice, that would have been totally unacceptable to a majority of farmers or other Americans.").

The Commissioner held similar power over processors and handlers. The power to set minimum milk prices to be paid to producers allowed the Commissioner to control directly the variable cost of milk processors. As discussed below, see infra notes 59-60 and accompanying text, the licensing provisions of section 258 allowed the Commissioner to control both fixed costs and the rate of technological change. The power to control retail prices coupled with the power to set the price paid to producers enabled 
before Hood, however, article 21 was substantially weakened. The provisions permitting the Commissioner to set farm quotas and retail prices were allowed to lapse. ${ }^{51}$ Of the Act's major original provisions, only those permitting the establishment of minimum milk prices and the licensing of milk dealers were retained. ${ }^{\mathbf{5 2}}$ The revised Act gave the Commissioner some control over farm incomes and the rate of farm failures and considerable control over the organization and structure of the milk processing business, but in the absence of direct power over farm production and producer revenues, the state exercised considerably less control than it once had over the direction of agricultural change. ${ }^{\text {s3 }}$

Federal law did not remedy these deficiencies. At the time of Hood's suit, federal agricultural law permitted the government to set minimum milk prices and to support prices by purchasing surplus milk $^{54}$ but permitted production controls only in exceptional circumstances. ${ }^{\text {sb }}$ Unlike article 21, federal law contained no provisions for

the Commissioner to control revenues. These powers interacted with the quota powers and the power to set transportation costs to give the Commissioner control over every variable affecting the milk processing industry: fixed costs, variable costs, rates of capital substitution, revenues, and distribution costs. See G. CRAmer \& C. JENSEN, supra note 18, at 147 (modeling graphically all variables affecting agricultural firms' output).

${ }^{51}$ The provisions allowing the Commissioner to set production quotas and retail prices were allowed to lapse for good in 1937. See R. INGALLS, supra note 22, at 170 (discussing Act of June 3,1937, ch. 876, 1937 N.Y. Laws 1977 (codified as amended at N.Y. AGRIC. \& MKTS. LAw \& 258-m (McKinney 1972 \& Supp. 1985))). Ingalls traces the erratic history of the lapsing and reinstituting of New York milk control laws in the period from 1934 to 1937 and presents a short discussion of some of the controversy that surrounded these laws. See id. at 148-72.

52 See Act of June 3, 1937, ch. 876, 1937 N.Y. Laws 1977 (codified as amended at N.Y. AGRIC. \& MkTs. LAW § 258-m (McKinney 1972 \& Supp. 1985)).

ss For a discussion of the effect of deleting quota provisions from New York's milk control laws, see R. Ingalis, supra note 22, at 170-72. See also supra note 49. The removal of the power to set retail prices shifted control over producer revenues to the market, but the revised law still provided a substantial measure of control over processors and distributors. See infra text accompanying note 59.

54 See Act of Aug. 24, 1935, Pub. L. No. 74-320, \& 8c(5), 49 Stat. 750, 754-55 (codified as amended at 7 U.S.C. $\S 608 \mathrm{c}(5)(1982)$ ); Act of June 3, 1937, Pub. L. No. $75-137, \S 2(\mathrm{f}), 50$ Stat. 246, 247 (codified as amended at 7 U.S.C. $\S 608 \mathrm{c}(18)(1982)$ ); see also House COMM. ON AGRICUlture, Agricultural ADJUSTMENT ACT Amendments, H.R. Rep. No. 1241, 74th Cong., 1st. Sess. 9-11 (1935) (discussing rationale for and means of fixing milk prices).

B5 Agricultural legislation of the 1930's provided for two different kinds of production controls. First, farm subsidy payments were linked to the voluntary curtailment of acreage. See Agricultural Adjustment Act of 1933, Pub. L. No. 73-10, § 8, 48 Stat. 31, 34 (codified as amended at 7 U.S.C. § 608 (1982)); see M. BENEDICT, supra note 19 , at $375 ;$ W. Cochrane, supra note 18, at 142-43; J. SchleBECKER, supra note 18, at 242-43. As discussed above, this approach failed to reduce production because farmers responded by taking their least productive lands out of production and increasing the intensity of their farming operations on the remaining lands, thereby increasing their output while receiving subsidies for taking land out of production. See supra note 
controlling distribution processes.

The minimum-price and government-purchase provisions of state

29. Second, the Secretary of Agriculture was authorized to impose marketing quotas if he found that production of a particular commodity was excessive and if two-thirds of the producers of that commodity agreed to the imposition of the quota. See Act of Aug. 24, 1935, Pub. L. No. 74-320, \& 8c(9), 49 Stat. 750, 758 (codified as amended at 7 U.S.C. $\S 608 \mathrm{c}(9)(1982)$ ). Although theoretically this power was considerable, it apparently was never exercised. See M. BENEDICT, supra note 19, at 376-77; G. FITE, supra note 17 , at 60 .

The beginning of the Second World War complicated the relatively simple picture presented above. In 1941, in response to wartime demand, national policymakers abandoned their unsuccessful attempts to restrict agricultural production and instead attempted to increase it. See M. BENEDICT, supra note 19, at 402-03. This latter program was hugely successful. See $i d$. at 441 table 2 (showing farm production increases from 1939 to 1945); W. CochRANE, supra note 18, at 137 (stating that the increase of $25 \%$ in farming output in the 1940's was the largest in the twentieth century). Farm prices also rose dramatically during this period. See id. at 123 figure 7.1 (indexes of farm prices and net farm income, 1910-1977).

As the war neared an end, however, the prospect of huge surpluses loomed. See, e.g., G. FITE, supra note 18, at 89. Although European and domestic demand kept prices high until early 1948, prices began to fall rapidly thereafter. See M. BENEDICT, supra note 19, at 463; G. FITE, supra note 18, at 87-89. In 1948, however, farm income dropped 15\%, and surpluses mounted. See R. Christenson, The Brannan Plan: Farm Politics and Policy 18 (1959); G. Fite, supra note 18, at 98-99. In 1953 and 1954, another recession precipitated another dismal decade for farmers. See G. FrTe, supra note 18, at 107 (Agricultural prices dropped 23\% between 1951 and 1956.).

As the following table indicates, New York milk prices followed this national pattern closely.

New York Milk Prices, 1940 to 1953

\begin{tabular}{ccc}
\hline Year & $\begin{array}{c}\text { Raw Price } \\
\text { per } 100 \text { Lbs. }^{\mathrm{a}}\end{array}$ & $\begin{array}{c}\text { Price Adjusted } \\
\text { for Inflation }\end{array}$ \\
\hline 1940 & 2.15 & 5.00 \\
1941 & - & - \\
1942 & 2.91 & 5.38 \\
1943 & 2.91 & 5.15 \\
1944 & 3.56 & 6.25 \\
1945 & 3.53 & 6.10 \\
1946 & 4.42 & 6.68 \\
1947 & 4.70 & 5.79 \\
1948 & 5.35 & 6.06 \\
1949 & 4.32 & 5.17 \\
1950 & 4.15 & 4.78 \\
1951 & 4.75 & 4.89 \\
1952 & - & - \\
1953 & 4.40 & 4.70 \\
\hline
\end{tabular}

Sources: Bureau of the Census, U.S. Dep't of Commerce, Statistical Abstract of the UNITED States 1963, at 351 table 468 (chart showing wholesale prices for 1940 to 1962); USDA, AGricultural STATiSTics 1940-1953 (tables on dairy farm products).

${ }^{2}$ Data for 1941 and 1952 were not available.

bBase years: 1957-1959. 
and federal law protected farmers against the most extreme swings in the volatile commodities markets and, therefore, against short-term losses. ${ }^{56}$ Under the conditions that have obtained in American agriculture in the twentieth century, however, minimum prices have had relatively little effect on the structure of agricultural development. ${ }^{57}$ As the decline in the number of farms, from 6.5 million to 2.4 million between 1920 and 1980, and the increase in average farm size, from 140 acres to 400 acres in these same years, vividly illustrate, ${ }^{58}$ minimum prices have affected the rate of agricultural change only slightly and the direction not at all.

The licensing provisions of section 258-c of article 21 provided a small but significant check on the forces leading to decreases in the farm population and increases in farm size and the intensity of farm use. These provisions allowed the Commissioner of Agriculture to control the size of processing operations and thereby to control the revenues of processors. ${ }^{59}$ When prices were near the minimum, the Commissioner also had a measure of control over processors' variable costs. Together these powers gave the state considerable power over the profitability of processing, and thus some effective control over the structure of the industry. Similarly, section 258-c allowed the Commissioner, within the constraints set by the aggregate demand for milk products, to determine the number and size of potential buyers of milk products and, therefore, to affect farmers' ability to participate in milk marketing. ${ }^{60}$ Finally, by determining the profitability of milk processing and

s8 This assumes, of course, that the minimum price is not allowed to float downward with the equilibrium price. On the characteristic volatility of the commodities markets, see G. GRAMER \& C. JENSEN, supra note 18, at 292 (discussing the relatively low elasticity of demand for farm products). See also id. at 292-93 (discussing variations in supplies of commodities and twentieth-century government policies for reducing price swings). For other discussions of the volatility of farm prices, see W. CochRANE, supra note 19, at 33-59; P. SAMUELSON, supra note 32, at 387; L. TWEETEN, supra note 17 , at 153 .

${ }^{87}$ See supra note 49.

${ }^{58}$ See G. FITE, supra note 18, at 101; J. Shover, supra note 18, at 6; USDA, supra note 20 , at 42 figure 5 .

${ }^{89}$ The Commissioner was able to control substantial technological change and expansion of size through section 258-c, which required the Commissioner's approval for any substantial modification or expansion of facilities. Processors might have tried to achieve savings in the cost of collecting milk by paying a premium for bulk purchases from large producers. The economic difficulties of the industry, however, limited the processors' ability to pay the higher prices. With demand usually lagging behind supply in the local milk industry, the retail margin would not encourage the payment of bonuses to large producers.

${ }^{60}$ Given the long-run tendency of technological change in twentieth-century America to increase the ratio of capital to labor in production, it seems likely that any expansion of a plant would have increased the capital intensity of the milk processing industry. In New York, the licensing provisions of section 258-c allowed the Commis- 
the organization of milk buying, the Commissioner could indirectly affect the prices paid to farmers.

Section 258 reflects the accurate perception that control of market processes is as critical as control of production to the organization of agriculture. $^{61}$ The high fixed costs of agriculture, the historical tendencies to overproduce, and declining per unit farm profits give the agricultural purchaser considerable leverage in negotiating prices. Farmers have few self-help remedies against purchasers. They are far from markets and dispersed from each other. Few have the capital or informational resources to market directly their products. As a result, purchasers have been able to keep prices low, and farmers have been unable to capture the profits of distribution and processing. ${ }^{62}$ Since 1950, the farmers' disadvantages have been exacerbated by increases in the size of, and decreases in the number of, food processors and distributors, so that today the largest part of the food dollar is captured by a few processors and distributors. ${ }^{63}$ In consequence, individual farmers are

sioner to control the rate of expansion and thus to influence the capital and managerial requirements for entering the processing business. It is reasonable to assume that farmers as a group would have been less able than large, specialized dairy firms to obtain the financing needed for constructing or purchasing milk processing facilities. It seems equally reasonable to assume that the greater the scale of operations needed for efficient milk processing, the less likely it would be that farmers would have the managerial skills and experience needed for competing successfully with established firms. See, e.g., T. Frey \& T. Behrens, Lending to Agricultural ENTERPRISEs 33-34, 56-58 (focusing on the characteristics of the farmer as a borrower).

61 This was the point of section 258. A hypothetically omniscient Commissioner of Agriculture would have been able to manipulate prices, costs, and technology to strike the culturally desired optimum balance between retail milk prices and the number of milk producers. The decision to deny Hood a license to build a new processing plant was an attempt to strike exactly this balance. See infra text accompanying note 72 . Whether the Commissioner had the knowledge necessary to strike the balance in this or any other case is beyond the scope of this Comment.

62 These observations summarize a substantial but scattered literature. See, e.g., W. Cochrane, supra note 18, at 292 (discussing the atomistic structure of farm markets); W. Cochrane, supra note 19, at 29-30 (The volatility of agricultural prices places farmers in the position of having to minimize losses.); J. ScHLEBECKER, supra note 18, at 293 (discussing the power of supermarket chains); J. SHOVER, supra note 18 , at 176 ("Family farmers . . . are scarcely involved at all in the modern marketing process . . . ."). Farmers, of course, have long felt that agricultural middlemen make exorbitant profits. See, e.g., J. Hicks, supra note 18, at 74-81 (detailing some of farmers' objections to middlemen in the late nineteenth century); J. SCHLEBECKER, supra note 18 , at 162 (Farmers in the mid-nineteenth century "often felt that middlemen made exorbitant profits.").

${ }^{63}$ For recent developments, see J. Schlebecker, supra note 18, at 293 (The supermarket share of the food retailing business increased from $20 \%$ to $52 \%$ between 1957 and 1969.); J. SHOVER, supra note 18, at 177 (noting that total marketing costs absorb two-thirds of every dollar spent on food); L. TwEETEN, supra note 17, at 207 table 7.7 (illustrating for the period from 1947 to 1965 the steadily declining share of retail food prices accruing to farmers); USDA, supra note 20, at 61-65 (discussing concentration in the food industry and finding that the 50 largest food manufacturers 
confronted with few choices among purchasers, and a small number of nationally organized food processors exert tremendous leverage on farm prices. To the extent that it impeded such concentrations of power, section 258-c was a potentially significant check on the forces leading to the transformation of agriculture.

That the power of section 258-c was less than that of the original articles 21 and 21A, or that section 258-c might have been less successful in practice than it was in theory, is irrelevant for present purposes, for the Supreme Court did not invalidate section 258-c because its provisions were too weak. ${ }^{64}$ What is relevant is the underlying theory of section 258-c: that if the social goal of preserving rural culture is to be achieved, farmers must be protected against the operation of the modern American agricultural market, and that to achieve this goal the structure of that market must be controlled.

The structural control of market organization is critical if the object is to preserve a particular regional rural economy and society. The development of modern capitalism has been marked by the increasing regional specialization of agriculture. ${ }^{65}$ Middlemen, such as Hood, have

controlled $74 \%$ of total national food processing capabilities in 1978).

The food processing industry approaches a monopsony. See, e.g., G. CRAMER \& C. Jensen, supra note 18, at 191-92; J. Shover, supra note 18, at 178-89; L. TWEeTEN, supra note 17, at 182-90. The essential characteristic of a monopsony is that the individual buyer is so dominant in the market that it can set its purchase price. In this situation, the profit-maximizing monopsonist does not permit the price to rise to the competitive equilibrium, the point at which its marginal revenue product equals the sellers' marginal cost. Rather, the monopsonist sets the quantity at a point where its marginal revenue product equals its own marginal cost and establishes the purchase price corresponding to that quantity on the market supply curve. See, e.g., R. PoSNER, supra note 12, at 230-31 (illustrating the profit-maximizing point for a monopsonist); J. RoBinson, THE Economics OF IMPERfect COMPETITION 218-28 (2d ed. 1969) (describing the economic principles of monopsony). The practical consequence is that a monopsonist maximizes profits by paying less and buying less than it would in a competitive market. Hood's application for a license to build a new processing plant was disallowed by the Commissioner exactly because he feared that Hood would achieve a monopsony in the Albany-Troy milkshed. See infra notes 70-87 and accompanying text.

- See infra text accompanying notes 93-95.

es Compare D. Rutman, The Husbandmen of Plymouth 43-48 (1972) (describing the varied output of Plymouth colony farms in the 1640's and 1650's) and J. Lemon, The Best Poor Man's Country: A Geographical Study of Early SOUTHEASTERN PENNSYLvanIa 150-51 (1972) (describing generally the mixed character of seventeenth- and eighteenth-century agriculture) with L. HAYSTEAD \& G. FrTE, The Agricultural Regions of the United States 7 map 7 (1963) (dividing the United States into 11 basic farming areas based on the proportion of farm revenues attributable to different crops) and D. Worster, DuST Bowl: THE SouTHerN PlaINS IN THE 1930's 150-54 (1979) (describing the specialized methods of wheat production used in Kansas during the 1930's). For a brilliant theoretical study of some of the economic causes of regional agriculture in the first phase of the modern era, see I. Wallerstein, The Modern World System I: Capitalist Agriculture and 
played a crucial role in this process of regional differentiation. By capturing the differences between the costs of the production and distribution of a commodity and the price of that commodity in a market, middlemen have profited and created capital. ${ }^{66}$ To exploit fully differences among farms and farming regions in marginal costs of production, the middlemen have steadily expanded their markets. ${ }^{67}$ As the middlemen's markets have expanded, agricultural regions have increasingly specialized in producing those commodities in which they have a comparative advantage.

Unless it furthers their interest in purchasing commodities at the lowest price, middlemen have no interest in the survival of any particular farm or farming region. Had milk been cheaper elsewhere, for example, Hood might well have reduced its offering price or level of purchases in the Albany-Troy milkshed, increasing competition among farmers and precipitating the consolidation of many farms into a few. In an extreme case, Hood's practices might have virtually eliminated dairy farming in the region. In either event, local society and culture would have been vastly altered or destroyed. Like any culture, rural culture is a distinctive social formation, dependent for its local forms on the particular organization of the local economy.

The observation that the social morphology $y^{68}$ of a particular rural

The Origins of the European World-Economy in the Sixteenth Century 63 (1974).

es See USDA, supra note 20, at 61-65; see also G. CRAMER \& C. JENSEN, supra note 18 , at $209-10$ (describing different classifications of middlemen). Barry Hindess and Paul Hirst, among others, have argued that the circulation of commodities is the very essence of capitalism. See B. Hindess \& P. Hrrst, Pre-Gapitalist Modes of Production 270, 304 (1975). For textbook accounts of the critically important role of trade in the early development of capitalism, see D. DowD, supra note 7, at 210-11; R. EDWARDS, M. REICH \& T. WEIsSKOPF, supra note 7, at 63.

67 Expanding the market area brings each farm into competition with more farms, increasing marginal differences in individual and regional productivity. For a discussion of the process of regionalization in dairy farming, see J. SCHLEBECKER, supra note 18, at 185. See also USDA, supra note 20, at 61-65 (arguing that concentration in the food industry increases tendencies toward regionalism).

68 The term "social morphology" refers broadly to the combination of economic and social structures that together make up what we speak of colloquially as the social fabric. See, e.g., E. Hobsbawm, InTroduction to K. MarX: Pre-Capitalist EcoNOMIC FORMATIONS 9-65 (1977) (summarizing Marx's attempt to analyze, as inseparable, social and economic relations of production). For one of the best studies of the relationship between economic and social structures, see W. Goldschmid, As You Sow (1947), a comparative study of large-farm and small-farm California communities. Goldschmidt found that small-farm communities have more voluntary organizations-churches, schools, and clubs-than do large-farm communities. See id. at 10117, 195-97, 210-12. These findings have been replicated repeatedly, and there is a considerable and growing literature that confirms what is intuitively obvious: namely, that industrial and rural communities have little in common. See, e.g., Poole, Farm Scale, Family Life, and Community Participation, 46 RuRAL Soc. 112, 121-22 
region is a function of the organization of agricultural production is particularly relevant to the cultural issue that was presented to the Court in Hood. Although New York milk prices had recovered from their Depression-era lows during the Second World War and had advanced rapidly in the years immediately after the War, by the time Hood was decided signs of trouble were at hand in rural New York. Small farms were failing; large farms were rapidly growing larger and becoming more heavily capitalized. ${ }^{68}$ If traditional rural culture were to survive in the region, some control of the organization of the market was essential.

In sum, article 21 was a piece of social legislation that was based on an accurate perception of the contemporary agricultural economy and designed to preserve farm communities. Section 258-c was applied by the New York Commissioner to protect a community from manipulation by outside capital at a time when the future of that community was severely threatened by the changing organization of agriculture.

\section{The Hood OpINIONS}

\section{A. The Commissioner's Decision}

The Hood suit began in March 1946, when H.P. Hood \& Sons, a large Boston dairy, applied to the New York Commissioner of Agriculture and Markets for a license to build its third milk processing plant at Greenwich, New York, in the Albany-Troy milkshed. ${ }^{70}$ Hood's primary stated reason for applying was that its two existing plants were incapable of processing milk quickly enough during the "flush season" to permit delivery in Boston by the 9:00 A.M. deadline required by local health codes. ${ }^{71}$ The Commissioner of Agriculture denied the application under section 258-c of article 21, on the grounds that construction of the new plant would "tend to a destructive competition in a market already adequately served" by Hood and other milk processors. ${ }^{72}$

(1981); Warner, Rural Society in a Post-Industrial Age, 39 RuRaL Soc. 306, 315 (1974).

${ }_{69}$ The number of New York farms selling milk declined from 83,891 to 62,522 between 1930 and 1949. See L. HAYSTEAD \& G. Frte, supra note 65, at 54. For a parallel situation, see H. SCHMIDT, Agriculture IN NEW Jersey: A THREe HuNDRED YEAR HISTORY 243 (1973) (The number of dairy herds in New Jersey declined from 17,624 in 1940 to 2000 in 1964.). For some of the effects of declining numbers of farms and increasing use of machines, see WPA, TRENDS IN EMPLOYMENT IN AGRICULTURE, 1909-1936, at 26 (1936) (showing a 27\% decline in agricultural employment in the eastern dairy region between 1909 and 1936).

${ }^{70}$ See Hood, 336 U.S. at 526-27; Record at 1-5, 27.

71 See Record at 24-25, Hood.

72 See Hood, 336 U.S. at 528-29. 
The Commissioner's findings were expressed in the capsule language of the statute. The hearing record suggests, however, that the license was denied because the Commissioner believed that Hood was attempting to gain control of milk distribution in the Albany-Troy milkshed. Hood planned to spend approximately $\$ 40,000$ to $\$ 50,000$ to build a receiving facility at Greenwich with a capacity of about 800 cans a day. ${ }^{73}$ During the previous year, Hood had expanded the storage capacity of its Eagle Bridge plant by $600^{\circ}$ cans a day. ${ }^{74}$ Together, these expansions would have increased Hood's local capacity by more than fifty percent, from 2600 to 4000 cans a day. Hood claimed that it expected to process only about 350 cans a day in the peak season at Greenwich and that it expected to attract only between twenty and thirty new producers to the new plant. ${ }^{25}$ These claims seemed starkly at odds with both the projected capital expenditures at Greenwich and the testimony of Hood's production manager indicating that the facility could process in fourteen minutes the entire volume of milk Hood claimed it would divert from Eagle Bridge. ${ }^{76}$ It seems implausible that Hood would have built the Greenwich facility intending to run it at less than half its capacity. Hood's proposed expansion seemed to be a bid for control of local milk production. Thus, the Commissioner reached the following conclusions: that Hood would likely use its substantial capital resources to raise initial prices to producers, thereby drawing their trade to its plants; that because of increased costs other plants would be forced to close; and that Hood would then cut prices to local producers. ${ }^{77}$

This scenario was plausible. At the time of its application to build at Greenwich, Hood was aggressively attempting to expand its already dominant position in the New England milkshed, and the company's strong capital position allowed it to sustain short-term losses to increase its market share. ${ }^{78}$ On the other side of the equation, the eight non-

7s See Record at 27-28, Hood (testimony of W.O. Whiting, Hood's Assistant Production Manager).

74 See id. at 31-32.

${ }^{76}$ See id. at 37-38 (testimony of G.L. Gould, Hood's Division Superintendent).

76 See id. at 33.

77 See Hood, 336 U.S. at 528-29. The Commissioner stated that Hood was able to pay temporarily higher prices because of the higher minimum prices permitted by the Boston Milk Marketing Board, noting that during the preceding season Hood had paid premium prices for grade A milk. See id.

${ }_{78}$ See A Resolution Creating a Select Committee to Conduct a Study and Investigation of the Problems of Small Business: Hearings on H.R. Res. 51 Before the Special Subcomm. of the House Select Comm. on Small Business, 86th Cong., 2d Sess. $452-53$ (1960) [hereinafter cited as Small Business Hearings]. Hood was the largest dairy processor in New England. See id. The ability of a large firm, like Hood, to sustain short-term losses underlies the practice of predatory pricing, whereby a large 
Hood processing plants in the Salem-Eagle Bridge-Greenwich area were all operating at well below full capacity. ${ }^{79}$ Any substantial diminution in the volume of milk they received would have raised their per unit costs above their marginal returns, driving them out of business. ${ }^{80}$ The perceived threat of monopsony, ${ }^{\mathbf{1 1}}$ in short, was solidly grounded in the economic facts of regional milk production.

In addition to considering the possible immediate effects of Hood's diversion of any significant part of the local milk supply, the Commissioner anticipated that Hood's expansion of its processing operations would have irreversible long-term effects on the structure of local dairying. This perception was also plausible. Hood's proposed expansion, if successful, would have increased the long-run average capital costs of milk processing. Thus, it would have become increasingly difficult for new processors to enter the market. ${ }^{82}$ Likewise, it was plausible that

firm cuts prices to the point of losing money in order to drive competitors out of business. See R. POSNER, supra note 12, at 223-33.

79 See Record at 56, 58, Hood.

80 The smaller plants' variable costs would have diminished as they produced less milk, but their fixed costs would have remained the same; apportioned over fewer units of milk, their average costs would have increased. See P. SAMUELSON, supra note 32, at 443 (Per unit cost equals total cost divided by the number of units produced.). The Commissioner relied heavily on a study by the Cornell University School of Agriculture that found that the volume of milk handled was the critical variable in determining the profits of a milk processor. See Record at 12, Hood (citing CoRnell UnIversitY AGricultural Experiment Station, Bull. No. 473, The Cost of Handling Fluid Milk and Cream in Country Milk Plants). The Commissioner also cited a February 1946 report of the New York State Temporary Commission on Agriculture that determined that 300 cans a day was the break-even point for a milk processor. See id.

81 As discussed above, supra note 63, a monopsony occurs when a single purchaser controls a market. In theory, one might expect monopsony power to be less effective in a situation such as that presented in Hood, where demand was generally lagging behind supply and federally established minimum prices had established a floor below which Hood could not drive prices. Milk production, however, is cyclical. In the dry season, even if demand lagged behind supply, there could be shortages causing temporary price surges. See, e.g., J. BLACK, supra note 28, at 183 (showing decreases in the milk supply between March and October). This seems to have been the case in the Albany-Troy region. According to the testimony in Hood, Troy suffered from regular milk shortages in the fall and winter. Hood, 336 U.S. at 528; Record at 51-52 (describing a shortage in Troy during the preceding season). In these time periods, monopsonistic power would be a substantial advantage. Furthermore, Hood originated in March 1946, in the immediate post-war period, when prices were still rising. See supra note 19 . The theory of monopsony suggests that it is exactly at such times that the monopsonist stands to gain the most.

82 The number of new entrants in any economic activity will be partly a function of the costs of entry. The higher those costs, the fewer the number of competitors that will have the capital or credit to enter. The railroad industry is an obvious example. See, e.g., R. POSNER, supra note 12, at 227-28.

It might be argued that if Hood could profit in the Albany-Troy region, then other competitors would enter the market. If Hood's profits were sufficiently large, this proposition would probably be true. Milk processors, however, were operating on slim 
once the economic ante of milk processing had been sufficiently upped, many small local processors would fail. ${ }^{83}$ Faced with these considerations, the Commissioner quite reasonably concluded that if Hood succeeded in obtaining a monopsonistic advantage, that advantage would likely endure.

The probable effects of Hood's expansion would have been particularly hard on local farmers who, in the years immediately before Hood's application, had attempted through local cooperatives to capture a part of the milk processing and distribution chain. ${ }^{84}$ A major obstacle to these efforts was the cooperatives' inability to capture a sufficient volume of milk to make processing profitable. ${ }^{85}$ Immediately prior to Hood's application, however, one cooperative had obtained a favorable contract with a dairy in the Greenwich area. ${ }^{86}$ Both the cooperative's membership and the Commissioner feared that Hood's expansion would jeopardize this contract, frustrating what seemed to be a promising remedy to local farm problems. ${ }^{87}$

To summarize, the denial of Hood's license was intended to prevent the Boston firm from obtaining a monopsony in the Albany-Troy milkshed. Had Hood obtained such an advantage, farm prices would have remained low even had demand risen faster than production. The capital requirements of Hood's contemplated expansion made it sub-

margins in 1946 and have continued to do so for nearly 40 years, making the profitability of the dairy industry slight. See, e.g., Small Business Hearings, supra note 78 , at 465-66 (focusing on the problems facing milk processors in the area surrounding Springfield, Massachusetts). Compare, e.g., USDA, Agricultural Statistics 1982, at 338 table 491 with USDA, Agricultural Statistics 1946, at 384 table 500 (The dairy industry has not been especially profitable since 1.946, and as a result over twothirds of the dairy farms in the New York reporting area went out of business between 1946 and 1982.). Thus, in reality, processors have had few incentives to enter new markets.

Although some local dairies might have been able to obtain sufficient credit to compete with Hood, and a few of their operators might have had the skill to expand their operations to a New England-wide operation, it is reasonable to conclude that many of the local dairies would have been unable to obtain the necessary credit or would have lacked the necessary managerial skill to do so. See supra note 60 .

8s Even if some small dairies and farmers could have entered the processing business, the oversupply of milk products would have sharply limited their potential. Given the relatively inelastic demand for agricultural products, competitors would have had to operate more cheaply than Hood to survive.

s4 See Record at 49-51, Hood (testimony of J.F. Pratt, Subdistrict President of the Dairymen's League Cooperative Association, describing the history of the League).

${ }_{\text {Bs }}$ See id. at 50-51. In an attempt to consolidate a sufficient supply to process milk profitably, the League had recently closed its own plant at Greenwich. See id. Farms).

86 See $i d$. at 62-63 (describing a local cooperative's contract with Gold Medal

82 Since volume of milk was the critical factor in successful processing, see supra note 80 , and the League was struggling to attain a sufficient volume, the loss of supply would clearly have hindered the League's success. 
stantially less probable that local producers or farmers could successfully compete for milk processing business. In the long run, the effect of the Greenwich plant would have been to reduce farm incomes and returns, erode farmer bargaining power, and exacerbate the economic forces leading to increases in farm size and decreases in farm numbers. ${ }^{88}$

\section{B. Justice Jackson's Majority Opinion}

The New York Supreme Court and the New York Court of Appeals upheld the Commissioner's decision. ${ }^{89}$ On appeal to the United States Supreme Court, Hood argued that the restrictions on its processing capacity impermissibly curtailed interstate commerce. In a five-tofour opinion, the Supreme Court accepted this argument.

Justice Stewart suggested that "[n]o man ever came to the Court with a larger concept of the federal commerce power"90 than Justice

88 As discussed above, supra text accompanying notes $17-23$, these economic forces led to a massive migration from farms to cities, decreasing the number of farms and farmers.

${ }_{89}$ See H.P. Hood \& Sons v. DuMond, 271 A.D. 394, 66 N.Y.S.2d 732 (App. Div.) (per curiam), 297 N.Y. 209, 78 N.E.2d 476 (1946), rev'd, 336 U.S. 525 (1949). Both New York courts relied partly on the Supreme Court decision in Nebbia v. New York, 291 U.S. 502 (1934). Nebbia upheld the provisions of article 25, which authorized the Commissioner to set retail prices for milk, on the grounds that milk production was a business imbued with a public interest and-in its most famous passage-on the rationale that "neither property rights nor contract rights are absolute; for government cannot exist if the citizen may at will use his property to the detriment of his fellows, or exercise his freedom of contract to work them harm." Id. at 523 (footnotes omitted). The appellate division of the New York Supreme Court confined its review to whether or not there were adequate grounds for the Commissioner's decision. See Hood, 271 A.D. at 395, 66 N.Y.S.2d at 733. But one judge noted that in Nebbia "the production of milk was determined to be a local business which might be regulated in the public interest and in the public welfare." Hood, 271 A.D. at 396, 66 N.Y.S.2d at 734 (Hill, J., concurring). On appeal, the state's highest court considered the constitutional issue and likewise found that the Commissioner's decision was the kind of local decision permitted by Nebbia. See Hood, 297 N.Y. at 215,78 N.E.2d at 478.

The United States Supreme Court had previously considered the validity of part of the New York milk regulation scheme and of a similar program operated in Pennsylvania. In Milk Bd. v. Eisenberg Co., 306 U.S. 346 (1939), the Court upheld Pennsylvania's right to impose licensing and bonding requirements on all milk processors and to regulate the prices paid to producers. The burden on interstate commerce was found to be "incidental and not forbidden by the Constitution." Id. at 353. In Baldwin v. G.A.F. Seelig, 294 U.S. 511 (1935), the Court sustained a commerce clause attack on New York's attempt to prevent the sale of milk from Vermont at wholesale prices lower than the prevailing wholesale price of New York milk. In Baldwin, the Court established the linguistic formulae that "the peoples of the several states must sink or swim together," id. at 523, and that a state may not establish "an economic barrier against" competition with the products of another state," $i d$. at 527 . This idea became one basis for Justice Jackson's opinion in Hood.

oo Stewart, Robert H. Jackson's Influence on Federal-State Relationships, in Mr. Justice Jackson, Four Lectures in His Honor 57, 68 (1969). 
Jackson and that the Hood opinion represented the "most extreme reach" of Jackson's expansive vision of national economic power. ${ }^{91}$ Stewart's evaluation is well founded. The tone of the Hood majority opinion is mythopoeic; its language is ebullient. In its most famous paragraph, Jackson's opinion made economic nationalism a core value of American constitutionalism:

Our system, fostered by the Commerce Clause, is that every farmer and every craftsman shall be encouraged to produce by the certainty that he will have free access to every market in the Nation, that no home embargoes will withhold his exports, and no foreign state will by customs duties or regulations exclude them. Likewise, every consumer may look to the free competition from every producing area in the Nation to protect him from exploitation by any. Such was the vision of the Founders; such has been the doctrine of this Court which has given it reality. ${ }^{92}$

In moving toward this paean to economic nationalism, Justice Jackson made three related arguments: (1) that section 258-c as applied to Hood curtailed competition by limiting the "volume of interstate commerce to aid local economic interests"; 93 (2) that the denial of Hood's application disrupted "normal" patterns of commerce;" and (3) that although New York might pass "social" legislation to aid farmers, it could not pass "economic" legislation like that which led to the denial of Hood's licensing application.95 None of these arguments followed ineluctably from either the facts of Hood or the application of economic or social principles to those facts.

Jackson's conclusion that section 258-c limited competition and curtailed the volume of interstate commerce is difficult to understand. The New York scheme was consistent with the very terms of his opinion: every farm had a market for its milk; section 258-c placed no limit on the amount of milk a farmer might produce or sell; and every local processor was free either to enter the Boston market or to export milk from New York. ${ }^{96}$ In short, the denial of the license to Hood affected

${ }^{91}$ Id. at 70.

${ }^{82}$ Hood, 336 U.S. at 539. But of. supra note 37 (comparing Jefferson's appreciation of farmers with his suspicion of merchants).

9s Id. at 530-31.

24 See id. at 537 (citing Toomer v. Witsell, 334 U.S. 385, 403-04 (1947)).

os See id. at 538.

${ }_{96}$ As observed above, see supra notes 61-62 and accompanying text, the immobility of agricultural capital limits short-run adaptations to market changes. Given the surplus of milk in the region, even if Hood had paid a short-term premium, that price increase would probably not have lasted long. See supra note 81. 
only the scale of the company's operations; it did not prevent the company from conducting interstate trade in milk. Moreover, section 258-c was designed and applied to prevent a single firm from obtaining a monopsony in the milk distribution business; that is, it was designed to increase rather than to diminish long-run competition for farm products. The principles that Jackson used to justify the Hood decision were poorly suited to the facts of the case.

This disjunction between principle and fact suggests that Jackson's decision followed from assumptions other than those he articulated. The "burden" on commerce that Jackson found in section 258-c was not quantitative or empirically discoverable. Rather, it was a predicted burden, grounded in assumptions about the probable operation of the market. To find that section 258-c burdened commerce, Jackson had to assume that by expanding the size of its operations Hood would achieve economies of scale, that these economies would result in lower retail prices and stimulate the demand for milk, and that in response to this demand milk production would increase. Given the prevailing economics of the milk industry, none of these assumptions was particularly well founded. ${ }^{87}$ More important, none had clear constitutional status.

97 Elasticities of demand are relatively low in agriculture. See, e.g., L. TwEETEN, supra note 17, at 197 . Thus, even if Hood had lowered retail prices it is unlikely that demand would have increased substantially. Because by 1949 there was already a burgeoning surplus of milk at low prices, any effect of a further diminution in prices would be small. More important, perhaps, Hood's ability to cut retail prices further was constrained by the federally required minimum wholesale price for milk, see supra note 54 and accompanying text, and by the competitive situation in the Boston milk market, where the spread between minimum and retail prices was relatively small. See, e.g., USDA, Agricultural Statistics 1947, at 385 tables 507-508, 387 table 510.

The most important point, however, is not that the Commissioner's economic reasoning was more plausible than Jackson's in the historical context of New York dairy farming, but rather that Jackson substituted his economic reasoning for that of the Commissioner. Given the absence of applicable federal law, there were no constitutional grounds that required him to do so. Prior commerce clause decisions that found impermissible restrictions on commerce rested on factual showings that the law in question presently burdened commerce, not on a theoretical prediction that there would be less of a good in commerce at some future point were the law upheld than there would be if the law were stricken. See supra note 7.

Under section 258, every gallon of milk produced in the Albany-Troy milkshed could have been shipped to the Boston market. Ironically, the only possible legal constraint on doing so was section 5-8c(5) of the Act of Aug. 24, 1935, Pub. L. No. 74320,49 Stat. 750,754 (codified as amended at 7 U.S.C. $\$ 608 c(5)(1982)$ ), which prohibited payment of federal minimum prices to new entrants in a market for a period of three months if those minimums exceeded minimum prices in the entrant's old market. This provision was intended to provide for the orderly expansion of milk marketing areas. By preventing New York competitors of Hood from obtaining high Boston prices, it prevented other marketers from competing equally with Hood in Boston. An argument could have been raised (but was not) that federal law prevented Hood's expansion of its facilities, on the grounds that Hood would be able to take advantage of the differential pricing created by this regulation and by the difference between New 
The interest that Jackson found constitutionally protected was that of agricultural buyers in expanding the size of their operations. And Hood can be read to state simply that the interests of economic entities in expanding their businesses cannot be constrained by any state's political process.

Similarly, Jackson's notion that the denial of a license to Hood disrupted "normal" channels of commerce by imposing an " "artificial rigidity on the economic pattern of the industry" "98 is difficult to understand as anything other than the constitutionalization of the interests of existing businesses. To begin, there is no such thing as a natural economy. Any economy is a human contrivance, and the only real choice we have is how to organize economic life. ${ }^{90}$ As article 21 implicitly recognized, the shape of any agricultural economy is determined by a complex set of humanly determined arrangements, including the state of technology, the size of market areas, and federal and state regulations. ${ }^{100}$ Justice Jackson's denial of the contingency of economic ar-

York and Boston minimum prices to obtain a purchasing monopsony and eventually to diminish the volume of milk flowing in interstate commerce. (1947)).

${ }^{98}$ Hood, 336 U.S. at 537 (quoting Toomer v. Witsell, 384 U.S. 385, 403-04

09 One commentator recently remarked that "[t]here are no free markets, only markets controlled by capitalists, kings, communists, or pirates." Address by George Gerbner, Dean of the Annenberg School of Communications of the University of Pennsylvania, A Symposium in Commemoration of the Trial of John Peter Zenger (Oct. 25, 1985) [on file with the University of Pennsylvania Law Review].

100 Any market or economy functions within the limitations set by a host of social institutions. Richard Posner notes, for example, that " $[t]$ he choice is rarely between a free market and public regulation. Ordinarily the choice is between two methods of public control . . . R. PosNer, supra note 12, at 271; see also P. SAMUELSON, supra note 32, at 41-42 (noting that choices within a market depend on the social distribution of wealth). See generally C. Lindblom, Politics and Markets (1977) (comprehensive analysis of the interaction between economics and social institutions). The laws of property, for example, determine what can be owned and what can be sold. The distribution of wealth determines who can pay what for which goods. Status and class determine who will have access to opportunities. For one of the best analyses of the relations between an economy, political theory, and beliefs about human nature, see C. MacPherson, The Political Theory of Possessive Individualism: HOBBES TO LOCKE 263-72 (1962) (summarizing the basic tenets of seventeenth-century liberalism, which are "peculiarly appropriate to a possessive market society because they state certain essential facts that are peculiar to that society"). As discussed above, see supra notes 95-99 and accompanying text, Jackson's assertion that the economic configuration of mid-twentieth-century America was somehow natural rather than time- and culture-specific is best understood as a way of reifying that configuration and protecting it from analysis.

The crux of the issue can be highlighted by a brief consideration of the ways in which economists of different persuasions view Adam Smith. Smith's contentions that humans are by nature inclined "to truck, barter and exchange one thing for another," that they are motivated principally by self-interest and are of differing talents, and that the interaction of these attributes produces a commercial society can all be taken as true for this consideration. See A. SMrth, AN InQUiRy InTo the Nature and Causes of 
rangements and his attribution of extra-human, "law-like" force to the contemporary economy was in effect a choice for the unconstrained operation of the existing market, whatever the cost for New York dairy farmers. By subordinating the human process of creating an economy to a higher-order generalization, Jackson foreclosed the possibility of positive statutory solutions to economic and social problems, at least by a state. $^{101}$

In more particular terms, Jackson's finding that section 258-c burdened commerce and disrupted the natural economic pattern of the milk industry effectively constitutionalized the existing distribution of industrial wealth. Hood's capacity to expand its New York operations was a function of its current capital position. That capital position was a function of the prior operation of the market, that is, of a historical process that took its particular form because of the distribution of wealth. ${ }^{102}$ In protecting Hood's future interest in obtaining possible economies of scale or a larger share of the Boston milk market, Jackson implicitly legitimated the distributional status quo.

But Jackson's opinion did not merely legitimate that status quo; it also enhanced Hood's relative position within it. Legal rules that shape the economic operations of a society are entitlements-that is, allocations of the right to engage in particular forms of economic behavior. ${ }^{103}$

The Wealth of Nations 12-16 (1966) (1st ed. London 1776). People, of course, are also inclined to subject others to their dominion and to rape, murder, and pillage, as well as to love, honor, and admire. What is at issue is what one does with what one takes to be human nature. Our society tends to regard the human propensity to protect one's self-interest as a good thing, as an attribute to be encouraged. See, e.g., P. SAMUELSON, supra note 32, at 1 . Other societies do not. See, e.g., C. LINDBLoM, supra, at 98-99. What we often forget is that the decision to give relatively free rein to one human propensity is historically specific. As MacPherson so exhaustively describes in his brilliant study of seventeenth-century thought, the English, at least, abandoned medieval notions of communality during that century and opted instead for a definition of humans as acquirers. See C. MAcPHERSON, supra, at 263-72.

101 Jackson's solution did not, of course, foreclose federal legislation on the problem. As discussed below, however, the deflection of discourse from the state to the national level affected enormously the possible outcomes of debate. See infra notes 154-68 and accompanying text. Given the rapidly diminishing power of rural interests at the national level, this deflection was in its practical effect a decision for the interests of nationally organized business. Justice Black's criticism of the majority focused in particular on this shift from the local to the national level. See infra notes 126-29 and accompanying text.

${ }_{102}$ As discussed above, see supra note 100 , the choices made in any market will be a function of the distribution of wealth, that is, of the constraints that limit the parameters within which individual preferences can be expressed. See, e.g., R. POSNER, supra note 12, at 10; P. SAMUELSON, supra note 32, at 41-42; Baker, The Economic Analysis of Law, 5 PhIl. \& PuB. AfF. 3, 14-15 (1975); Tribe, Policy Science: Analysis or Ideology, 2 Phil. \& Pub. Aff. 66, 79-81 \& n.36 (1972).

${ }_{103}$ One of the best sustained demonstrations of this principle is Richard Posner's Economic Analysis of Law. See R. Posner, supra note 12. As Posner shows, any legal 
Jackson might have described his Hood decision as simply the transfer of the right to control the size of Hood's New York operations from the state legislature to Hood. But he did not. By describing Hood's right to expand as "natural," he gave law-like status to a highly contingent bundle of economic rights. In so doing, he effectively insulated business size from control by political processes.

As Jackson noted, New York could continue to pass social laws, for the commerce clause did not authorize "federal interference with social conditions" in the states. ${ }^{104}$ This notion of a sharp, discoverable distinction between social and economic legislation, mirroring a supposedly similar distinction in the world, ignored the exact problem that both the Depression and article 21 placed squarely before the Supreme Court and the nation: namely, that there is no way to separate social from economic conditions. ${ }^{105}$ The attempt to divide legally the complex

decision has economic consequences, because as a result of the decision people may or may not perform acts that in turn have value. To pick but one example, if monopolies were legal then valuable rights would be allocated differently than if they were illegal. See id. at 231-36. In Hood, the right to expand was valuable to Hood; the right to keep Hood from expanding was valuable to smaller, traditional New York farmers. Whatever the outcome, the decision represented an allocational choice.

Such choices can be made only with reference to normatively grounded criteria for determining how rights should be allocated. It is the courts' function in our society to articulate those criteria. People can and do disagree deeply about them. See, e.g., C. LiNDBLOM, supra note 100, at 76 (noting that markets are good for some things and not for others); R. POSNER, supra note 12, at 10-12 (arguing that efficiency, defined as the set of choices that would be made given the prevailing forms of social and governmental organization and the prevailing distribution of wealth, should be the normative basis for making decisions); Baker, supra note 102, at 8 (arguing that the "economic analysis of [a] legal dispute cannot take the distribution [of wealth and rights] as given since the dispute is over what the distribution is"); Tribe, supra note 102, at 106 (criticizing approaches such as Posner's for their tendency to "warp reality in certain patterned ways").

104 Hood, 336 U.S. at 534.

105 Karl Polanyi argues that a similar intellectual operation was at the heart of the liberal transformation of western society in the nineteenth century. See K. Polanyi, The Great Transformation: The Political and Economic Origins of OUR TIMES 68-71 (1957). In brief, Polanyi argues that this transformation was grounded in the idea of the "self-regulating market." In his terms, traditional societies regarded the economic order "as a function of the social, in which it was contained. [Thus, nineteenth-century] society, in which economic activity was isolated and imputed to a distinctive economic motive, was, indeed, a singular departure." Id. at 71. As Polanyi notes, a bifurcation of culture into "economic" and "social" spheres underlies two basic "liberal" precepts: the state should not allow anything to inhibit the formation of markets, and sales should be the only permissible source of income. Id. at 69 . The result, according to Polanyi, was the subordination of society to the laws of the market. Id. at 71.

A full study of the notion that social matters may be separated from economic matters and of the effect that this proposition has had on the development of American constitutional doctrine would require many pages. No one would deny that social and economic conditions can be plausibly isolated from each other for the purposes of study. An anthropologist can study a kinship system, for example, without investigating its 
whole that is society serves only to subordinate social reality to economic theory. Article 21 was an attempt to structure the modern economy to mitigate its harshest effects upon the farm communities of New York. Its failure to pass constitutional muster meant that no rural locality could insulate itself from these effects, even if such insulation neither affected interstate commerce in any quantitative, immediate way, nor discriminated between the citizens of different states.

The theoretical, legal, and economic consequences of Jackson's reasoning, then, were enormous. The primary assumptions of the opinion-that the existing distribution of wealth and the right of business to expand were "natural"- - disjoined economics from politics. The assumption that society existed apart from its economic underpinnings shifted control of social processes from politics to the market. By subordinating politics, society, and the Constitution to the market, Jackson confirmed the social and economic status quo. In the process, New York's dairy farmers were flung back upon that market. Over time, they went out of business. ${ }^{108}$

economic characteristics. In doing so, however, the anthropologist is not claiming that a kinship system has no economic characteristics, but only that for the purposes of clarity she is choosing not to focus on them. Jackson's claim, however, seems to presuppose that social and economic domains are in fact isolated.

A simple example demonstrates the problematic character of this formulation. Most would concede that the "family" is a social institution. Yet it is clear that the family structure has profound economic consequences. Societies that practice partible inheritance, for example, will generally be characterized by smaller landholdings and different methods of agricultural organization as compared with societies practicing primogenitary inheritance. Alternatively, it is equally clear that when the economic bases of partible inheritance are eroded by the continued parceling of lands to the point where owners can no longer earn a living from their holdings, new inheritance patterns may be created. See, e.g., P. Greven, Four Generations: Population, Land, AND FAMILY IN ANDOVER, MASSACHUSETTS 136 (1970). In short, the social institution of inheritance and the economic practice of agriculture are inseparable.

In Hood, Jackson seemed to be saying that whatever interest New York farmers or milk processors may have had in living in communities of small-scale enterprises was not a social interest, even though such an interest would seem preeminently social. As discussed below, see infra notes 142-44 and accompanying text, Justices Black and Frankfurter in dissent recognized the inseparability of social and economic institutions and framed the matter as a problem of federalism, namely, of determining which domains of social and economic life would be allocated to the states and which to the federal government. Article 21, like much other agricultural legislation during the Depression, recognized the inseparability of social and economic phenomena and sought to achieve a particular desired social configuration by manipulating the variables in the economic equation. See supra notes 44-50 and accompanying text. In effect, Jackson was saying that this social solution was not constitutionally acceptable.

${ }_{108}$ The number of New York farms declined from about 150,000 in 1946 to about 49,000 in 1982. Compare USDA, Agricultural, Statistics 1982, at 386 table 556 with USDA, Agricultural Statistics 1946, at 525 table 579. 


\section{The Hood Dissents}

The majority opinion in Hood closed a quarter century in which the reach of the federal commerce power was the subject of continual constitutional debate. ${ }^{107}$ By weaving together deep oppositions in American culture-between farmer and businessman, country and town, past and present, legislature and court, and state and nation-into a vision of an America sustained by ceaseless growth, productivity, and prosperity, Justice Jackson's opinion maintained metaphorical touch with the past at the very moment that it moved unhaltingly into the future. This rhetorical sleight of hand did not go unnoticed or uncontested. In separate dissents, Justices Black and Frankfurter attacked Jackson's vision, preferring apparently the older, small-scale world that Hood was leaving behind.

The dissenters organized their disagreement with Justice Jackson around the subtle but significant shift in commerce clause analysis effected by the Hood majority opinion. In their view, Jackson's opinion was a radically "new constitutional formula"108 that rested on a sweeping reevaluation of the Court's role in interpreting the commerce clause. ${ }^{108}$

Their first point of attack was doctrinal. As Justice Black observed, article 21 was the result of extensive and careful study ${ }^{110}$ of the social and economic problems at which the law was aimed. ${ }^{111}$ Depression history, Black argued, showed these ills to be pervasive, ${ }^{112}$ and the New York law provided an appropriate means for their alleviation. ${ }^{113}$ Article 21, he continued, did not discriminate against interstate commerce, nor had it been applied discriminatorily to Hood. ${ }^{114}$ Thus, Black concluded, although due process considerations might invalidate laws that were ill-considered, irrational, or overbroad, commerce clause doctrine could be used only to invalidate laws that discriminated in purpose or application against interstate commerce. In Black's view, no constitutional standard yet enunciated by the Court justified Jackson's

107 See supra note 7.

${ }_{108}$ See Hood, 336 U.S. at 545 (Black, J., dissenting).

109 See id. at 563 n.14.

110 See id. at 546.

111 See id. at 547.

112 See id. at 546 (citing Nebbia v. New York, 291 U.S. 502, 515-16 (1934)).

11 See id. at 547.

114 See id. at 549. Black also observed that had a New York milk dealer wished to expand, its application also would have been rejected, and had a New York dealer wished to send his milk to Boston, article 21 would not have precluded the shipment. See id. at 548. 
conclusion. ${ }^{115}$

The dissenters' second point of attack was factual. As Black characterized it, article 21 did not burden commerce in any empirically identifiable way. ${ }^{116}$ Rather, it channeled milk in and out of New York in a manner that the people of the state found desirable. In his words, "there [was] no evidence whatever to show that fair enforcement of the . . . law would limit the total volume of New York milk available for shipment into other states."117 Given that the burdens Jackson discovered were not actual but theoretical, Black again concluded, prior case law did not require invalidation. ${ }^{118}$

Justice Frankfurter analyzed the issue somewhat differently. Even if article 21 "burdened" commerce, he argued, the very idea of the commerce clause was that it was "sometimes-of course not always-of greater importance that local interests be protected than that interstate commerce be not touched." "[G] "[G]ommerce interpenetrates the States," " Frankfurter noted, " 'and no undisputed generality about the freedom of commerce from state encroachment can delimit in advance the interacting areas of state and national power . . . ." "120 In Frankfurter's view, the federal system required a resolution of the tensions between state and federal sovereign governments, economies, and social systems; to resolve such conflicts without exploring their substantive social and economic implications was to avoid the challenge of the Constitution.

Regardless of their differences in approach, the dissenters agreed that a court confronted with the kind of deep-seated social and economic conflict presented by Hood should evaluate closely the competing interests at hand-the interests of farmers and industrialists, state and nation, legislatures and Court. Black expressed the matter succinctly, arguing that "decision on such an issue required a consideration of facts such as the nature of the regulation, the character of the business, [and] the regulation's actual effect on interstate commerce."121 Justice Frankfurter was more oblique, concluding his argument with a long list of rhetorical questions regarding the economy of the Albany-Troy region, the dairy business there, and the commercial impact of the law. ${ }^{122}$

${ }^{115}$ See id. at 552, 554-55.

116 See id. at 561 .

117 Id.

118 See id.

119 Id. at 567 (Frankfurter, J., dissenting).

120 Id. (quoting Union Brokerage Co. v. Jensen, 322 U.S. 202, 210 (1944)).

121 Id. at 553 (Black, J., dissenting).

122 See id. at 573-74 (Frankfurter, J., dissenting). 
Both dissenters rejected out of hand Justice Jackson's transposition of a complex substantive and normative discourse about the structure of social and economic life into the mechanical application of a theoretical economic principle. The majority, they argued, had substituted abstract principles for the concrete confrontation with social and economic reality that the commerce clause demanded and had shirked the Court's duty to resolve economic, social, political, and ideological conflict. ${ }^{123}$ The result was to free many businesses entirely from regulation and to render elected representatives impotent to frame rules to govern this dynamic civilization. ${ }^{124}$

The dissenters similarly contested the rigid dichotomization of social and economic life that was the critical first step in the intellectual process by which Justice Jackson elevated to constitutional status the existing distribution of legal and political rights and wealth. To protect Hood from the burden of section 258-c was to protect that distribution as well. In contrast to Jackson, both dissenting Justices conceptualized social and political processes as ongoing contests between different groups and interests. Inevitably, such deep-seated conflicts would require resolution by the Court. The proper response was not to retreat to reified abstractions, but to make normative judgments on the basis of substantive considerations. Indeed, both dissents suggested that the abstracted approach of Justice Jackson merely concealed the judgments that necessarily were being made.

In Frankfurter's terms, the majority simply preferred the interests of the merchant to those of farmers. ${ }^{125}$ Justice Black was more vehement. In his view, the decision removed most local business from regulation, ${ }^{128}$ unleashed aggressive cupidity upon American life, ${ }^{127}$ and in the process resurrected the discredited philosophy of Lochner $v$. New York: ${ }^{128}$

The judicially directed march of the due process philosophy as an emancipator of business from regulation appeared arrested a few years ago. That appearance was illusory. That philosophy continues its march. The due process clause and commerce clause have been used like Siamese twins in a never-ending stream of challenges to government

${ }^{123}$ See id. at 545, 551-52 (Black, J., dissenting); id. at 568 n.2 (Frankfurter, J, dissenting).

124 See id. at 545 (Black, J., dissenting); id. at 563 (Frankfurter, J., dissenting).

125 See id. at 573 (Frankfurter, J., dissenting).

126 See id. at 545 (Black, J., dissenting).

127 See id. at 562.

128198 U.S. 45 (1905). 
regulation. . . .

. . . Both clauses easily lend themselves to inordinate expansions of this Court's power at the expense of legislative power. ${ }^{129}$

Black's invocation of Lochner was telling. Like Hood, Lochner preferred business concerns to social concerns, ${ }^{130}$ but the similarities between the two decisions were not merely in their results. Like Hood, Lochner was grounded in the assumptions that economic and social life could intelligibly be kept separate in legal analysis and that legal decisions could be made on the basis of principles independent of the particular social and economic conflict before the Court. ${ }^{131}$ In recalling Lochner, Black sought to discredit not only the Hood result, but also its jurisprudence. To use constitutional doctrine to protect commerce from a future burden predicted by an economic theory, he seems to have been suggesting, was to prevent the Court from playing out its proper cultural role as an arbiter of society's conflicts, and to commit it instead to a particular theory of political economy. In short, the dissenters conceptualized the Court not as an enforcer of rules, but as a participant in an ongoing process of culture building.

On the basis of an inquiry into the actual effects of article 21, Justice Black would have upheld the statute. Its principal purpose, in his characterization, was to promote the general welfare by protecting farmers from impoverishment and insolvency. ${ }^{132}$ Taking a page from Jackson's book of economic theory, Black argued that, given the structure of the agricultural market, the possibility of monopsony in the Albany-Troy region was real ${ }^{133}$ and the possible effects could be disastrous for farmers. ${ }^{134}$ Under the rule of Nebbia $v$. New York, ${ }^{135}$ he

129 Hood, 336 U.S. at 562-63 (Black, J., dissenting) (footnote omitted).

1 so See 198 U.S. at 57-58 (relying on the fourteenth amendment's guarantee against deprivations of liberty without due process of law to overturn a bakery owner's misdemeanor conviction under a New York statute that prohibited workweeks of longer than 60 hours for bakery employees).

131 Lochner has become one of the most consistently reviled decisions the Court has ever rendered. Cited approximately 300 times between 1943 and 1984, see 2A Shepard's United States Citations Case Edition (5th ed. 1984), Lochner is invoked nearly universally to suggest that the proponents of a disfavored view have committed the "Lochnerian fallacy" of permitting their values, instead of someone else's, to dictate their judgment. In Hood Black used Lochner as a means of noting the value-laden bases of Justice Jackson's seemingly neutral reasoning. His argument, in short, was that value-free law is a contradiction in terms because law is about values, however much one may try to obscure them.

132 See Hood, 336 U.S. at 546 (Black, J., dissenting).

139 See id. at 547-48.

134 See id. at 546.

19s 291 U.S. 502, 515-16 (1934). 
concluded, Hood's business interest had to give way to the general welfare as defined by the legislature of New York. ${ }^{136}$ It was not for Justice Jackson to substitute his notion of a properly structured market for the kind of society that the people of New York had chosen to try to create. ${ }^{137}$

In contrast to Black, Justice Frankfurter would have remanded the case for further inquiry. ${ }^{138}$ This procedural difference, however, does not obscure Frankfurter's essential agreement with Black. Given the importance that the Court had previously attached to the regulation of agriculture, Frankfurter argued, it seemed incomprehensible to assign, as a matter of law, a "higher . . . place to milk dealers' standards of bookkeeping than to the economic well-being of their industry."139 Like Black, he argued that such legislation properly promoted the general welfare. ${ }^{140}$ The clear tenor of Frankfurter's opinion is that he would have upheld the law upon any showing that it was reasonably calculated to achieve its objectives.

Justices Jackson, Black, and Frankfurter had all served the New Deal well. ${ }^{141}$ Their thought was deeply grounded in the experiences of the Depression. But whereas Justice Jackson understood the future to lie with an ever-expanding market, Justices Black and Frankfurter reached toward a formulation of that future grounded in an alternative social vision. Like Justice Brandeis before them, Black and Frankfurter distrusted deeply the forces of centralized power. ${ }^{142}$ Like Brandeis, they denied that social and economic questions were meaningfully separable $^{143}$ and believed that law could be understood only by understanding

${ }^{136}$ See Hood, 336 U.S. at 549 (Black, J., dissenting).

137 See id. at 563-64.

138 See id. at 575-76 (Frankfurter, J., dissenting).

139 Id. at 573.

140 See id. at 572.

141 See E. Gerhart, America's Advocate: Robert H. Jackson 240 (1958); V. Hamilton, Hugo Black: The Alabama Years 260 (1972); H. Thomas, Felix FRANKFURTER: SCHOLAR ON THE BENCH 23-41 (1960).

${ }^{142}$ See, e.g., J. Frank, Mr. Justice Black: The Man and His Opinions 56 (1949) ("To Black, the militant enforcement of the antitrust laws was the only antidote that could save a free capitalist system . ..."); H. THOMAS, supra note 141, at 92 (describing Frankfurter's role in drafting New Deal legislation that limited industrial power); Henkin, Voice of a Modern Federalism, in FELIX FRANKFURTER: THE Judge 71 (W. Mendelson ed. 1964) (describing Frankfurter's "federalist" belief that the diffusion of power promoted democracy).

${ }_{143}$ This Comment does not purport to address the rather complicated theoretical matter of whether either Justice Black or Justice Frankfurter would have believed that social and economic matters were separable. Rather, what is important for present purposes is their rejection of the practice of using deductive, a priori categories of "social" and "economic." See, e.g., Ferguson v. Skrupa, 372 U.S. 726, 730-33 (1963) (Black arguing, as he does in Hood, see supra text accompanying notes 110-17, that a state legislature should be free to frame rules that shape society without distinguishing be- 
its impact on society. ${ }^{144}$

In recognizing that Justice Jackson had solved the problem in Hood by means of a set of unarticulated assumptions about the nature of the modern economy, Black and Frankfurter recognized also that he had imported into commerce clause doctrine a particular vision of American society that contradicted that of the New York legislature. In noting that Jackson's analysis resurrected, albeit in a new form, the substantive due process language of an earlier judicial era, they rightly observed that the majority opinion ultimately and ineluctably removed from the citizenry the power to determine how social and economic rights should be allocated.

Justice Black's response to Jackson's celebration of the new American marketplace was grounded in the Populism of his Alabama boyhood. Throughout his career, Black remained the self-styled "candidate of the masses" that he was in his first congressional election; ${ }^{145}$ throughout, an odd admixture of individualism, deep distrust of large institutions, and a search for popular control of society and the economy guided his public progress and judicial reasoning. ${ }^{146}$

By comparison with Black's response to Jackson, Frankfurter's opinion was cerebral, echoing more the halls of Harvard than the streets of a southern town, ${ }^{\mathbf{1 4 7}}$ grounded more in an analytic understanding of American culture, history, and politics than in the immediate experience of rural society. Frankfurter's response was motivated by a profound respect for the organic nature of social organization, a deep appreciation of the fragility of human society, and a keen sense that a way of American life was passing. ${ }^{148}$

tween rigid social and economic categories); H. THomas, supra note 141, at 88 (Frankfurter stating that "in a civilization like ours where the economic interdependence of society is so pervasive, a sharp division between property rights and human rights largely falsifies reality" ") (quoting F. FRANKFURTER, MR. JUSTICE HOLMES 50 (1938)).

144 See J. Frank, supra note 142, at 139; H. Thomas, supra note 141, at 97.

145 See J. Frank, supra note 142, at 65.

146 See G. Dunne, Hugo Black and the Judicial Revolution 85 (1977) (describing Black's attachment to his Clay County, Alabama roots); J. Frank, supra note 142, at 11 (describing Black's philosophical affinity with poor whites).

147 See H. ThOMAS, supra note 141, at 5-7.

148 See F. Frankfurter, Mr. Justice Brandeis and the Constitution, in Law and Politics: Occasional Papers of Felix Frankfurter 1913-1918, at 119 (1971). Less than a decade before Hood, Frankfurter had written:

The ultimate foundation of a free society is the binding tie of cohesive sentiment. Such a sentiment is fostered by all those agencies of the mind and spirit which may serve to gather up the traditions of a people, transmit them from generation to generation, and thereby create that continuity of a treasured common life which constitutes a civilization. "We live by symbols." 
Yet although the Hood dissenters began at different points and traveled different paths, a consistent set of assumptions integrated their dissents: a reverence for the traditional values of small-scale rural democracy and a deep suspicion of judicial actions that removed the people's control over the shape of their society. Above all else, however, what separated Black and Frankfurter from Jackson was their vision, rooted in the American past and tracing its heritage ultimately to Jefferson, of a smaller, more individualized, less centralized society. Hood was a major failure-and possibly, in the sphere of constitutional economics, a final failure-for this ideal.

\section{The Historical ConText of Hood}

The controversy in Hood arose at the end of a long struggle for political control over the direction of American economic life. Beginning in the last years of the nineteenth century, nationally organized industries began to exert increasing control over the American economy. ${ }^{148}$ Against the forces of massed capital stood a relatively disorganized array of groups, including populists, social reformers, and labor, that never achieved the level of organization and singularity of purpose at-

Minersville School Dist. v. Gobitis, 310 U.S. 586, 596 (1940); see also H. Thomas, supra note 141, at 45-68 (discussing Frankfurter's notion of culture and cultural symbols).

140 See $\mathrm{R}$. HofsTADTER, supra note 18, at 252 (describing the implementation of the Sherman Antitrust Act in the early years of the twentieth century). Hofstadter notes that
despite the widespread public agitation over [trusts], the men who took a conservative view of the needs of the hour never lost control. . . . It proved impossible for men like Bryan and LaFollette, who did not enjoy the confidence ... of the business community, to find their way to the White House ....

Id. at 250. For a general survey of the rise of monopolies in the closing years of the nineteenth century, see H. FAULKNER, Polirics, REForm AND Expansion, 1890 1900 , at 72-93 (1963). For more particularized accounts of the new social and political order that was taking shape in the years around the turn of the twentieth century, see T. Cochran \& W. Miller, The Age of Enterprise: A Social History of INDUSTRIAL AMERICA 140-46 (rev. ed. 1961) (describing the rise of trusts, including U.S. Steel and Standard Oil); $i d$. at 151-53 (describing the increasing nationalization of American economic life and the rising power of industrialists); id. at 342-48 (describing the efforts of business to eliminate regulation in the 1920's). See also J. ChamberLaIN, The Enterprising Americans: A Business History of the UnIted States 181 (3d ed. 1963) (describing the coalescence of business power at the national level in the first quarter of the twentieth century); G. Kolko, The Triumph of ConservativISM: A REINTERPRETATION OF AMERICAN HistORY, 1900-1916, at 282 (1963) ("The ideological consensus among key business leaders and political leaders fed into a stream of common action . . . ."); R. WIEBe, The SEARCH FOR ORDER, 1877-1920, at 29396 (1967) (describing political and industrial aspects of the solidification of national bureaucratic control over American life). 
tained by their opponents. ${ }^{150}$ Economic organization became increasingly national in scale, and the opponents of capital were forced increasingly to contest the "fact" of the modern society.

From a short-term point of view, the Depression was the decisive stage in a process by which the acceptance of a national economy of industrial capital became a reality. Although some still continued to argue that this reality, like all others, was contingent and therefore malleable, the crucial political decision of the Depression was the decision to accept a national economy and to locate the struggle for control of that economy in national politics. ${ }^{151}$

Hood was one of the last in a line of Supreme Court opinions that confirmed this configuration of power. That process of confirmation involved three discrete intellectual operations. First, as observed above, the prevailing economic structure and distribution of wealth were validated as "natural" or given. ${ }^{162}$ Thus, they were legally incontestable. Second, the operation of the modern economy was validated as desirable. Thus, even if the national economy was not "real" in the same way as, say, the law of gravity, it was a good thing. Finally, Justice Jackson validated his opinion by referring to the myth of the founders. ${ }^{153}$ Thus, even if the national economy was neither real nor desirable, it was constitutional. With this integration of the law of nature, the idea of the good, and the sanction of tradition, Hood marked a symbolic and rhetorical end of the dispute over the proper locus of economic control and provided a synthesis of values under the aegis of national economic policy.

This national synthesis disadvantaged the less powerful-workers as well as farmers-and substantially increased the political power of industrial capital relative to that of other social interests. National politics requires money, communications, and organization, areas in

150 For classic, if now dated, surveys of the plethora of reform movements in the beginning of the twentieth century, see E. Goldman, Rendezvous WITH DestinY: A History OF MODERN AMERICAN REFORM 48, 63 (1952) (describing the differences between populists and socialists and populists and progressives); R. HorstadTER, supra note 18, at 266 (noting the inability of progressive reformers to articulate a workable program for dealing with the changing economic structure of society, and describing the reform movements as an attempt to institutionalize a "mood" of discontent).

151 See, e.g., W. Leuchtenburg, Franklin D. Roosevelt and the New Deal 34 (1963) (describing theorists of the New Nationalism as the most influential in forming New Deal ideology, and describing the Roosevelt brain trust's uniform rejection of the Brandeis view that the problems of American life would be solved if America once more became a nation of small proprietors) (citing R. TUGWELl, THE Democratic RoOsevelt 213 (1957)).

152 See Hood, 336 U.S. at 537-38; see also supra text accompanying notes 102-03.

18s See Hood, 336 U.S. at 539. 
which industrial capitalists have substantial advantages. ${ }^{154}$ The deflection of farm issues to national politics effectively precluded the representation of local farm interests and allowed expression to the interests of only those farmers for whom profits were more important than local culture. Most important, the very notion of a national farm interest, itself deeply embedded in the structure of modern industrial society, contradicted the organizing principles of traditional rural culture.

The obverse of the rise of a national industrial culture is the decline of the traditional rural community. Historically, such communities were identifiable economic units, integrated only imperfectly into national or world economies. ${ }^{155}$ Although they typically produced for the market, such communities maintained a local political economy organized less around maximizing market production than around the use and allocation of resources among members of the community. ${ }^{156}$ In contrast to the particularized and fragmented society of modern urban communities, the social organization of the traditional rural community was typically "dense."157 Social relations were formed in a complicated array of settings, including work, school, church, local politics, and voluntary organizations. Status was thus determined in a social matrix rather than along a wealth continuum. ${ }^{158}$

164 See R. Miliband, The State in Capitalist Society 161-62 (1969).

165 See, e.g., T. Cochran \& W. Miller, supra note 149, at 211 (describing the demise of local economies in the years after the Civil War); A. VIdich \& J. BENSMAN, Small Town and Mass Society: Class, Power and Religion in a Rural ComMUNITY 55-57, 67-69 (1958) (describing the major difference between "rational" and "traditional" local farmers in terms of the degree to which they respond to outside economic forces); R. WIEBE, supra note 149, at XIII (arguing that America during the nineteenth century was a nation of island communities). For the classic theoretical statement, see R. Redfield, Peasant Society and Culture 28-29 (1960) (describing peasant societies as societies in which the world of the market only partly absorbs the local social world).

156 See R. REDFIELD, supra note 155, at 30 (describing the segregation of local peasant markets from the larger national market). The classic examples in American history are the first Puritan communities of New England, in which all members of the town were given some land and in which unallocated land was held by the town for distribution to subsequent generations. See, e.g., P. GREveN, supra note 105, at 41-54. The classic examples in the European context, of course, are the common fields of the late medieval village. See id. at 43.

167 For a relatively modern example, see A. VIDICH \& J. BENSMAN, supra note 155, at 230 (describing the interaction of kinship, marriage, and family tradition in determining church membership); $i d$. at 282 ("Decision making in the community is not a specialized function.").

${ }^{188}$ For a classic American example, in which a person's worth was defined by a complex mixture of wealth, perceived godliness, family connections, education, age, and varied personal attributes, see E. Cook, The FATHERS of THE Towns: Leadership and Community Structure in Eighteenth Century New England 23-62 (1976) (analyzing in detail the influence of wealth, family, education, and other variables on the choice of leaders in eighteenth-century New England towns); id. at 92-93 (describing the concept of "usefulness," which was used in determining social status for 
Although such communities could never retain all of their young in the face of demographic growth, their "belief" systems were grounded in the principles of stasis and replication. ${ }^{169}$ As a result, even though agricultural villages regularly discharged surplus population to the labor market, they still represented a substantial impediment to the development of a fully capitalist organization. Local institutions provided support mechanisms that partly removed the individual from the pales of market psychology. The curtailment of individual accumulation in the interest of maintaining the community diminished the potential supply of industrial labor and slowed the rate of capital accumulation and concentration. Wide distribution of property ownership insulated the community from market forces. A world view organized around stasis was incompatible with the ceaseless changes of industrial life. ${ }^{160}$

Focusing on the historical depth of the migration from agricultural communities, however, obscures at least as much as it reveals. The largest proportional displacement of rural peoples in our history has occurred in the three-and-one-half decades since $1947 . .^{161}$ In 1948, when Hood was being written, approximately twenty percent of all Americans still farmed. ${ }^{\mathbf{1 6 2}}$ In the 1950's, the farm population decreased by more than seven million people, ${ }^{163}$ and in the 1960 's, the exodus continued at the rate of 600,000 people per year. ${ }^{164}$ Today, only three percent of the American people still farm, ${ }^{165}$ and only about ten percent still live in places that might be counted as traditionally rural. ${ }^{166}$

purposes of seating at meetinghouses, as a combination of age and public service). For an example of the continuing vitality of affiliational status patterns, see A. VIDICH \& J. BENSMAN, supra note 155, at 260 (describing overlapping leadership roles).

159 For a basic statement of the difference between pre-industrial agrarian belief systems and industrial, nonagrarian belief systems, see Thompson, Time, Work, Discipline and Industrial Capitalism, 38 PAST \& PRESENT 56 (1967). For other discussions, see H. Gutman, Work, Culture and Society in Industrializing AMERICA 19-22 (1976) (describing the pre-industrial work habits of the first generation of American factory workers); C. Hill, Society \& Puritanism in Pre-IndusTRIAL ENGLAND 226 (1972) (describing the development of new work habits in the first phase of the transition to industrial capitalism).

160 See H. GuTMan, supra note 159, at 19-22.

181 See G. CRAmer \& C. JenSEN, supra note 18, at 29 table 2-6.

162 See id.

163 See id.

164 See id.

16s See Bitter Harvest, supra note 29, at 55.

${ }^{186}$ As demographers have observed, it is impossible to obtain a precise count of the proportion of the population living in places that conform to what is meant by "rural." Most census data for rural areas are reported under the category of "nonmetropolitan counties," which includes counties on the fringes of major cities. See Powers \& Moe, The Policy Context for Rural Research, in RuRAL SOCIETY IN THE UNITEd StATES: Issues FOR THE 1980's 14 (D. Dillman \& D. Hobbs eds. 1982). The $10 \%$ figure is a "guesstimate" achieved by halving 54 million-the total number of 
Hood, then, stood at a critical juncture in the transformation of America-between a still substantially rural America and modern, urban America. In rejecting New York's attempt to structure its relationships with Boston capital so as to maximize the possibility of preserving local, rural culture within the national social system, the Hood majority endorsed principles lying at the heart of the displacement of people from the land and the replacement of one form of society and world view by another.

The idea of the small community is apposite to an understanding of Justice Jackson's opinion in Hood not only because the idea describes the socio-historical reality that the Hood opinion rejected, but also because it provides an alternative to the idea of social organization endorsed in Hood. In American idiom, that alternative is the Jeffersonian ideal of a relatively small-scale, participatory democracy. ${ }^{167}$ Hood removed the control of local economics to the national legislative and political processes. American politics at the national level provides only for a kind of formalistic citizen participation and denies to the individual any real possibility of an effective role in decisionmaking. ${ }^{168}$ Individual interests are atomized in national politics, and it is relatively easy for the organizations of capital to capture the key institutions of national government. The world that Hood sanctioned is a world in which individuals have limited ability to shape their economic and social experience. Hood, to be blunt, authorized the imperialism of the market and sanctioned the existing distribution of wealth without providing for meaningful opportunities to define the limits of wealth or the contours of the market.

It is neither surprising nor ironic that the Supreme Court's confirmation of the new national industrial order and rejection of the ideal of the traditional small rural community came in the context of a challenge to agricultural legislation that was designed to preserve traditional rural life. In invalidating that legislation, Hood invalidated that way of life no less than it invalidated the means of preserving it. In its historical context, Hood stands as one of the moments in which our

nonmetropolitan residents-and dividing that quotient by 220 million. See also Johnson \& Beegle, The Rural American People: A Look Forward and a Look Backward, in RuRAL Society IN THE UNITED STATES, supra, at 61.

${ }_{187}$ See supra note 37 and accompanying text.

168 The theoretical formulation used here tracks closely that of Ralph Miliband. See R. Miliband, supra note 154 . For some particularly relevant passages dealing with the relationship between nationalism and the loss of power by some groups, see id. at 157 (Business is never as divided as labor.); id. at 162 (The business interest is always claimed to be the national interest.); id. at 171 (describing the general trend of legislatures to lose power as industrial capitalism expands). 
culture abandoned the rural ideal it had cherished for more than three centuries, and accepted instead the new industrial world.

\section{CONCLUSION}

By 1948, when Justice Jackson was writing his opinion in H.P. Hood $\mathcal{E}$ Sons v. Dumond, the United States had recovered from the Depression and was entering an era of sustained national prosperity. The farm economy, however, verged again on recession. ${ }^{169}$ After a brief respite during and after World War II, farmers across the land again faced the familiar prospect of declining prices. What they could not know was that the coming years would change their lives more than any similarly short period in the nation's history. ${ }^{170}$ Agricultural productivity would triple and average farm size would quadruple, but farmers' numbers would be thinned nearly by half until farmers constituted just three percent of our population. American life was about to be transformed as abruptly and as significantly as it had earlier been transformed by the opening of the west and the coming of the industrial revolution. In the wake of this transformation, Jefferson's chosen people would become the people left behind. ${ }^{171}$

In finding that section 258-c of the New York Agriculture and Markets Law impermissibly burdened interstate commerce, Justice Jackson substantially expanded national power by constitutionalizing the market economy with respect to state economic legislation. In doing so without suggesting an alternative way for farmers to remedy their plight, Jackson placed rural localities everywhere at the mercy of economic forces beyond their control. Grounded in the microeconomics of nationalism, his opinion shifted responsibility for economic and social legislation to national politics. The failure of these politics is another story. That they failed with respect to traditional rural culture is by now obvious, for with the prosperity of the 1950's came also the depopulation of rural America and the final capitalization of agriculture and the countryside.

Such stories about the working out of social processes do not really end, but they do have moments that look like endings. And something that looked like the end of this story came on June 26, 1973, when the Wall Street Journal ran an advertisement that pictured four young men standing in front of a barn and silo. The advertisement read,

160 See G. FITE, supra note 18, at 95.

170 See id. at 88 (comparing the magnitude of change in rural life during the late 1940 's with the transformation brought on in the 1890's by the closing of the frontier).

171 See J. SHOVER, supra note 18, at 102-03; see also supra notes 36-37. 
"Your industry needs what these boys learned on the farm. They learned how to work. Hard!"172 The transition documented in this advertisement, from ownership and control of one's labor to dependence on the capital of others, is of course the centuries-long transition to capitalism. It is a transition whose last phases were, in part, legally validated by Hood and accelerated by the kind of thinking on which that opinion was based. That Jackson himself was a country boy who had served liberal causes well as Roosevelt's Attorney General ${ }^{173}$ only underscores the irony of America's liberal alliance with capital.

173 See E. GerharT, supra note 141, at 240. 
